\title{
Des clercs qui se mesleront de faire lettres et obligations*
}

\section{Public notaries and comital vassals or hommes de fief in the organization of voluntary jurisdiction in late-medieval Hainaut (1345-1467)}

Falco Van der Schueren

\section{Summary}

During the late Middle Ages, the organization of voluntary jurisdiction in the customary regions of the Southern Low Countries was strongly determined by local developments. While it thrived in the major bishoprics of Liège and Tournai as well as in the commercial centers of Flanders and Brabant, historiography long assumed that the notary public failed to integrate into society in the more rural county of Hainaut. Competition with the more dominant aldermen and comital vassals or hommes de fief supposedly prevented notaries from institutionalizing their role as private legal intermediaries. Yet, the long-held top-down perspective disregarded interactions between, and the mutual competition among these different 'agents', thus creating a unilateral view that emphasized the importance of existing or indigenous alternatives. This contribution aims to better comprehend the organization of

\footnotetext{
* The title of this contribution is drawn from an excerpt of a charter that was issued by count William IV of Hainaut (1365-1417) on July 7, 1410 in Mons: "Item, des clercs qui se mesleront de faire lettres et obligations, nuls d'iaus ne se polra ne devera porter, comme nos hommes de fief, au recevoir et passer tels obligations avoec un nostre autre homme de fief tant seullement; mais vollons que se chuils clercs se y porte comme homs, ce soit avoec deus autres nos hommes de fief, ou autrement les obligations ne vauront; et se uns clercs et uns autres homs avoec lui s'avanchent pour chou faire et passer entre yaus deus seullement, avoec ce que l'obligation ne vaura, cescuns d'iaus d'eus sera à sissante sols blancs d'amende enviers nous." See: L. Devillers, Cartulaire des comtes de Hainaut, de l'avènement de Guillaume II à la mort de Jacqueline de Bavière, 3, Brussels 1886, p. 465; C. J. B. F. Faider, Coutumes du pays et comté de Hainaut, [Recueil des Anciennes Coutumes de la Belgique], 1, Brussels 1871, p. 101. This contribution is a summary of my master's thesis at Ghent University: F. Van der Schueren, Ars notariatus Hanoniensis. Openbare notarissen en hommes de fief in de organisatie van vrijwillige rechtspraak binnen laatmiddeleeuws Henegouwen (1345-1467) (unpublished master's thesis), Ghent 2019.
} Because of their critical remarks that helped shaping this study, I owe many thanks to Prof. Dr. Els De Paermentier and Prof. Dr. Dirk Heirbaut, both affiliated at Ghent University. 
late medieval voluntary jurisdiction in Hainaut, taking the co-existence of public notaries and hommes de fief into consideration. From a bottom-up approach, relying on contemporary documentary writing practices, it will demonstrate how they both employed pragmatic literacy to gain authority, claim fides publica, and consolidate their own institutional position as such. This paradigm shift offers a framework that nuances previous insights regarding the reception of and developments within the notarial office in late medieval Hainaut.

\section{Keywords}

voluntary jurisdiction - pragmatic literacy - notary public - feudalism - customary law Middle Ages - Hainaut

\section{Notaries nowadays: socially relevant or outdated?}

Early August 2018, Justice Minister Koen Geens (CD\&V) received an expert report about the future of the Belgian notarial office ${ }^{1}$. Geens shared the positive assessment by both its authors $^{2}$, but at the same time he acknowledged their concerns about the high financial costs: a reform would guarantee the rates and fees to be an accurate representation of the notary's service $^{3}$. The public opinion considers this reform pledge to be insufficient and has profound

\footnotetext{
${ }^{1}$ This report was prepared by Pierre Nicaise and Thierry Van Sinay, honorary chairmen of the Koninklijke Federatie van Belgische Notarissen and the Nationale Kamer van Notarissen: L. Pinti, Plan over de toekomst van het ambt van notaris, URL: www.koengeens.be (uploaded on June 30, 2018); P. Nicaise and T. Van Sinay, Juridische beroepen voor de toekomst, een toekomst voor juridische beroepen: het notariaat, Brussels 2018, p. 7.

${ }^{2}$ According to the authors, the notary public has always been able to ascertain a prominent role in society, since it can easily respond to societal evolutions. At the same time, this explains why the 'customer satisfaction' is relatively high and why the notary, next to the family doctor, establishes the highest degree of confidentiality with his clients: Nicaise and Van Sinay, Juridische beroepen (supra, n. 1), p. 11-14 and p. 44-49.

${ }^{3}$ M. Verbergt and S. Andries, Minister van Justitie Koen Geens, 'Ik beloof: de notaris wordt goedkoper', URL: www.standaard.be (uploaded on September 3, 2018).
} 
reservations about the added value of notaries in our current society ${ }^{4}$. Moreover, central to the social debate are the questions whether the notarial profession should be abolished for the benefit of digital alternatives, such as blockchain ${ }^{5}$, and whether voluntary jurisdiction should receive a different interpretation today. However, a straightforward answer is missing, especially since the office is rooted in a historical tradition dating back to the thirteenth century $^{6}$. In turn, this makes the history of the medieval notarial practice significant once again: to contextualize the importance of public notaries for contemporary voluntary jurisdiction, and to nuance their value in respect to different private legal entities or intermediaries (e.g. aldermen and comital vassals $)^{7}$.

\footnotetext{
${ }^{4}$ Particularly socialist politicians have long been in doubt of the notarial office: J. Van Horenbeek,
} Hervormingsrapport. Sp.a: 'Notariskosten moeten niet omlaag. Ze moeten verdwijnen', URL: www.demorgen.be (uploaded on August 8, 2018). Hugo Lamon, attorney and director-spokesman of the Orde van Vlaamse Balies, pointed out that such a demeanor is borne by many others as well: H. Lamon, Opinie. Zijn er nog advocaten, notarissen en deurwaarders nodig? URL: www.vrt.be (consulted on February 6, 2019).

${ }^{5}$ A blockchain is a list of records that is administered by a network of interconnected instances or persons instead of one central entity. As such, blockchain reduces the role of intermediaries and makes their share more transparent: M. Vandersmissen, Moet het notariaat op de schop? Schaf het notariaat voor eenvoudige taken af, URL: www.knack.be (uploaded on March 7, 2018). Also see the commentary of the former president of Jong VLD: M. Van de Reyde, Schiet niet op de notaris, maar stem onmondige politici weg, URL: www.knack.be (uploaded on March 10, 2018).

${ }^{6}$ For a general overview of the history of the notarial office in the Southern Low Countries, see among others:

M. Oosterbosch, M. Vleeschouwers-Van Melkebeek, P. Pieyns-Rigo and P. Godding, Het notariaat in de Belgische territoria tijdens de middeleeuwen, in: Het notariaat in België van de middeleeuwen tot heden, ed. C. Bruneel, P. Godding and F. Stevens, Brussels 1998, p. 11-94; C. M. Cappon, Het notariaat in de late middeleeuwen $( \pm 1250- \pm 1540)$, in: Het notariaat in de Lage Landen $( \pm 1250-1842)$. Opstellen over de geschiedenis van het notariaat in de Lage Landen vanaf de oorsprong tot in de negentiende eeuw, ed. A. F. Gehlen and P. L. Nève, [Ars Notariatus, 117], Deventer 2005, p. 1-29; F. Stevens, Histoire du notariat en Belgique, in: Handbuch zur Geschichte des Notariats der europäischen Traditionen, ed. M. Schmoeckel and W. Schubert, [Rheinische Schriften zur Rechtsgeschichte, 12], Baden-Baden 2009, p. 361-374.

${ }^{7}$ Scientific research into the medieval notary public of the (Southern) Low Countries has a long tradition dating back to the mid-eighteenth century: Pieter van der Schelling, Histori van het notarisschap, behelzende den oorsprong, 't begin, en den voortgang van het notarisschap, Rotterdam 1745. Voluntary jurisdiction as a specific research topic only gained attention from the early twentieth century onwards: H. Nelis, Étude diplomatique sur le tabellionage royal de Tournai au Moyen Âge (1367-1521), Bulletin de la Commission Royale d'Histoire, 73 (1904), p. 1-142; H. Nelis, Les origines du notariat public en Belgique (1269-1320), Revue Belge de Philologie et d'Histoire, 2 (1923): p. 267-277; H. Nelis, Les doyens de chrétienté. Étude de diplomatique sur leurs actes de 
The existing historiography into the organization of voluntary jurisdiction in the Southern Low Countries during the late Middle Ages, nonetheless, often offers a unilateral view due to the scientific research approaching the subject from a mere top-down perspective, emphasizing the institutional developments of the dominant agents that recorded private $\operatorname{deeds}^{8}$. In the main bishoprics of Liège and Tournai, among others, those were episcopal notaries, whose presence from the second half of the thirteenth century onwards was related to the rise of officialities, as well as their public counterparts several decades later ${ }^{9}$. These public officials were equally prosperous in the urbanized and commercial centers of Flanders and Brabant. There they were mostly active in the mercantile sphere, though they also recorded, competing with the aldermen, deeds on behalf of religious institutions or private individuals ${ }^{10}$. This was not the case in the county of Hainaut, where the notary public barely

juridictions gracieuse en Belgique au XIIIe siècle, Revue Belge de Philologie et d'Histoire, 3 (1924), p. 59-73; H. Nelis, Étude diplomatique sur la juridiction gracieuse des échevins en Belgique (1150-1300), Annales de la Société d'Émulation de Bruges, 80 (1937), p. 1-57.

${ }^{8}$ To a lesser extent, the diplomatic aspect equally received attention, though the emphasis was mainly on the formal characteristics of notarial instruments: V. Gaillard, Marques et signatures des notaires, Annales de la Société Royale des Beaux-Arts et de la Littérature de Gand, 6 (1855), p. 184; E. Vanden Bussche, Les notaires d'autrefois, comment ils signaient leurs actes, La Flandre. Revue des Monuments d'Histoire et d'Antiquités, 2 (1868), p. 123-124; J. Yernaux, Les notaires publics du XIIIe au XVIe siècle spécialement au Franc de Bruges, Bulletin de la Commission Royale d'Histoire. Académie Royale de Belgique, 82 (1913), p. 111-182. Fernand Discry elaborated on the importance of notarial minutes for the issue of an authentic instrument: F. Discry, Les minutes des notaires. Étude de diplomatique, in: Mélanges d'histoire offerts à Charles Moeller à l'occasion de son jubilé de 50 années de professorat à l'Université de Louvain 1. Antiquité et Moyen Âge, ed. l'Association des Anciens Membres du Séminaire Historique de l'Université de Louvain, [Recueil de Travaux publiés par les Membres des Conférences d'Histoire et de Philologie, 40], Louvain 1914, p. 548-562. From the 1980s onwards, there was a growing interest in prosopographical approaches that focused on both the social and cultural backgrounds of (public) notaries. See for relevant references: infra, n. 11.

${ }^{9}$ P. Pieyns-Rigo, Notaires d'officialité et notaires publics au service de l'officialité liégeoise (1252-1337), Bulletin de la Commission Royale d'Histoire, 132 (1966), p. 297-332; M. Vleeschouwers-Van Melkebeek, Notaires d'officialité dans le diocèse de Tournai au XIIIe sciècle, in: Horae Tornacenses (1171-1971). Recueil d'études d'histoire publiées à l'occasion du viIIe centenaire de la consécration de la cathédrale de Tournai, ed. L. E. Halkin, H. Platelle and N. Huyghebaert, Tournai 1972, p. 199-214.

${ }^{10}$ See for Brabant: M. Oosterbosch, Het openbare notariaat in Hasselt tijdens de middeleeuwen (14e-15e eeuw), Het Oude Land van Loon, 37 (1982), p. 223-273; M. Oosterbosch, Het openbare notariaat in Oost-Brabant tijdens de middeleeuwen: institutionele aspecten, Historica Lovaniensia, 138 (1982), p. 17-27; M. Oosterbosch, De notaris in de Tiense samenleving tijdens de middeleeuwen, De Brabantse Folklore, 246 (1985), p. 90-119; M. 
pervaded society, due to the firm grip on voluntary jurisdiction by aldermen and comital vassals or hommes de fief ${ }^{11}$. Though this area has received lesser attention so far, previous and limited research into it has clearly shown that indigenous alternatives to the notarial office did exist and that they were embedded in local customs ${ }^{12}$. As a result of that predominantly institutional framework, however, these competing and co-existing intermediaries were neglected, underexposing their mutual interactions ${ }^{13}$.

\section{Alternative approaches and innovating perceptions}

\subsection{Pragmatic literacy as point of departure}

As stated in the introduction, this contribution offers a more nuanced view of both the specific interpretation of voluntary jurisdiction in late-medieval Hainaut and the way in which various agents within the legal field mutually differentiated ${ }^{14}$. Other than previous studies, this current one revolves around a bottom-up perspective that considers both the constituent's point of

Oosterbosch, Het openbare notariaat in Antwerpen tijdens de late middeleeuwen (1314-1531). Een institutionele en prosopografische studie in Europees perspectief (unpublished $\mathrm{PhD}$ dissertation), Louvain 1992. Regarding Flanders, see among others: J. M. Murray, Notaries public in Flanders in the late Middle Ages (unpublished PhD dissertation), Illinois 1983; J. M. Murray, W. Prevenier and M. Oosterbosch, Notarial instruments in Flanders between 1280 and 1452, Brussels 1995.

${ }^{11}$ A. Cacheux, Les notaires dans le ressort de la coutume de Mons en Hainaut français aux XVIIe et XVIIIe siècles, The Legal History Review, 28 (1960), p. 42-58; A. Louant, Les hommes de fief sur plume créés à la cour féodale de Hainaut de 1566 à 1794. Origine du notariat en Hainaut, [Recueil des Tablettes du Hainaut, 1], Hombeek 1960. Since the archives of the medieval benches of aldermen in Mons were destroyed due to the fire of 1940 ( $c f r$. infra), research into the importance of aldermen to the local contemporary voluntary jurisdiction are lacking.

12 This is also the case for other regions such as Flanders and Brabant, although historians rather tend to approach these indigenous alternatives (e.g. aldermen) from their administrative or governmental background.

${ }^{13}$ Nelis, for instance, did treat the separate institutions, but failed to acknowledge the mutual interactions between these different recording instances: supra, n. 7.

${ }^{14}$ Here, however, the emphasis is on comital vassals or hommes de fief and public notaries who were active in and near the county of Hainaut. Due to the precarious conditions of the archival sources from the benches of aldermen in Hainaut, the aldermen have not been considered: supra, n. 11. 
view and the contemporary legal practices, and that approaches the overall theme taking the former documentary writing practices in the Southern Low Countries into consideration. From the twelfth century onwards, the writing process in Europe knew a radical transformation moving from a rather ad hoc practice to a more routinized and institutionalized one $^{15}$. In this regard, Hagen Keller wrote about the pragmatische Wende as a form of bureaucratization characterized by the rise and spread of pragmatic literacy among society's lay segment ${ }^{16}$. This type of lay literacy arose from the practical consideration to record, preserve and consult transactions ${ }^{17}$.

This study will examine to what extent such a bureaucratization appeared in late-medieval Hainaut concerning the recording of deeds of voluntary jurisdiction, or how public notaries and comital vassals (hommes de fief) in the fourteenth and fifteenth century employed pragmatic literacy in their mutual competition to gain professional authority as private legal recording instances. As such, this line of questioning implies a correlation between 'pragmatic literacy' on the one hand, as well as 'authority', 'institutionalization' and 'authenticity' on the other $^{18}$. After all, a scribe or author could claim an institutionalized form of power since he possessed prerogatives ex officio through which he was entitled to issue a written document. Referring to these prerogatives, he was able to consolidate his professional status and record a transaction in a charter that gained authority itself. The validation signs or guarantees

${ }^{15}$ F. Menant, Les transformations de l'écrit documentaire entre XIIe et XIIIe siècles, in: Écrire, compter, mesurer. Vers une histoire des rationalités pratiques, ed. N. Coquery, F. Menant and F. Weber, Paris 2006, p. 35; C. F. Briggs, Literacy, reading and writing in the medieval West, Journal of Medieval History, 26 (2000), p. 398.

${ }^{16}$ H. Keller, K. Grubmueller and N. Staubac (eds.), Pragmatische Schriftlichkeit im Mittelalter. Erscheinungsformen und Entwicklungsstufen, [Münstersche Mittelalter-Schriften, 65], Munich 1992. Malcolm B. Parkes was the first to introduce the notion of 'pragmatic literacy' to fully grasp the diversity of medieval lay literacy: M. B. Parkes, Scribes, scripts and readers. Studies in the communication, presentation and dissemination of medieval texts, London 1991, p. 275.

${ }^{17}$ Parkes, Scribes, scripts (supra, n. 16), p. 275; M. T. Clanchy, From memory to written record. England 10661307, Oxford 1996, p. 258-65; Menant, Les transformations (supra, n. 15), p. 33-34.

${ }^{18}$ Following Parkes, Richard H. Britnell elaborated on pragmatic literacy and assumed a correlation between institutionalization, power and authenticity: R. H. Britnell, Pragmatic literacy in Latin Christendom, in: Pragmatic literacy. East and West, 1200-1330, ed. R. H. Britnell, Woodbridge 1997, p. 3. See also: A. Murray, Reason and society in the Middle Ages, Oxford 1990, p. 213-314. 
mentioned in the text equally imposed authority, inasmuch that they reaffirmed and protected the charter, and ensured the authenticity of the written document ${ }^{19}$.

Taking these reflections into consideration, the main research question can be elucidated from three concrete sub-questions: (1) to what extent was the role of hommes de fief and public notaries regarding voluntary jurisdiction institutionalized and how did this contribute to the reinforcement of their institutional or professional authority; (2) in what different legal aspects of society could they assert their institutional or professional authority and claim public trust or fides publica; (3) through which discursive formulas or material and graphic signs (signa) could these agents guarantee the authenticity of their own writings and consolidate their institutional or professional authority?

\subsection{Critical remarks with the source material}

Besides an alternative approach of the general theme involving the notion of 'pragmatic literacy', the added value of this contribution equally lies in the composition of the source corpus. Key to this, is a rather unique fifteenth-century formulary from Hainaut that was probably compiled by one or several hommes de fief $f^{20}$. Unfortunately, very little is known about this manuscript, especially since it has somehow been neglected in current studies ${ }^{21}$. For example: its precise origins and context of use are hardly known, and the exact span of time in which it was compiled, is difficult to determine, since most of the templates do not contain an explicit datatio $^{22}$. Based on the oldest and youngest texts that have been

\footnotetext{
19 These reflections coincide with Michel Zimmerman's theoretical and methodological approach towards the medieval notion of authority, that considers the representation of authority as the key aspect of the expedition of a private deed or public charter, which in turn manifests on the level of the author, the document and the guarantees: M. Zimmerman, Affirmation et respect de l'autorité dans les chartes, in: Les actes comme expression du pouvoir au Haut Moyen Âge. Actes de la Table Ronde de Nancy, ed. M.-J. Gasse-Grandjean and B.-M. Tock, [Atelier de Recherches sur les Textes Médiévaux, 5], Turnhout 2003, p. 215-17.

${ }^{20}$ Ghent University Library (G.U.L.), Manuscripts, ms. 2304. See for a brief and codicological description of the manuscript: A. Derolez, H. Defoort and F. Vanlangenhove, Medieval manuscripts. Ghent University Library, Ghent 2017, p. 259.

${ }^{21}$ An introduction to and critical edition of the formulary is in preparation. See also: F. Van der Schueren, Ars notariatus Hanoniensis. Openbare notarissen en hommes de fief in de organisatie van vrijwillige rechtspraak binnen laatmiddeleeuws Henegouwen (1345-1467) (unpublished master's thesis), Ghent 2019, p. 28-33.

${ }^{22}$ The datatio in a charter offers an indication about the time frame in which the document was issued. It usually
} 
incorporated, dating respectively from 1406 and 1446, the formulary was probably composed during the first half of the fifteenth century ${ }^{23}$. Meanwhile it is certain that the manuscript, now belonging to the Ghent University Library collection, was transferred to Ghent before 1923 due to an exchange transaction with the States Archives in Mons ${ }^{24}$. Because of this, the formulary was saved from the fire that burst out in the capital of Hainaut on May 14, 1940 and destroyed huge parts of the archives ${ }^{25}$. Additional traces concerning the textual tradition of this unique source are missing, as they were lost during the catastrophe of the Second World $\mathrm{War}^{26}$.

Apart from this fifteenth-century formulary, this contribution incorporated many other documents and primary sources in which hommes de fief and notaries acted as either the issuer of the negotium or the author of the instrumentum in the county of Hainaut between 1345 and $1467^{27}$. Chronologically, these documents align with the period in which the main source of this study, the formulary, was presumably compiled. This timeframe corresponds with the reigns of William IV and Jacqueline of Hainaut (1401-1436), and partially with that of Philip the Good (1396-1467) ${ }^{28}$. To better map diachronic evolutions, the preconceived span

contains a date and occasionally a place name: M. M. Cárcel Ortí (ed.), Vocabulaire international de la diplomatique, [Commission Internationale de Diplomatique. Comité International des Sciences Historiques], Valencia 1997, p. 132.

${ }^{23}$ Even though these dates function respectively as the terminus post quem and the terminus ante quem for the manuscript's redaction span, additional paleographical research should be able to provide a definite answer concerning the identity of the authors and the exact period in which the formulary was composed.

${ }^{24}$ Van der Schueren, Ars notariatus (supra, n. 21), p. 32-33.

${ }^{25}$ G. van Dievoet, Notarisboeken en formulierboeken voor notarissen in de Zuidelijke Nederlanden van 1500 tot 1800, in: Forma servata. Vijf opstellen over formulieren en formulierboeken in het notariaat van de middeleeuwen tot vandaag, ed. P. L. Nève and J. J. Verbeek, [Ars Notariatus, 85], Deventer 1998, p. 76.

${ }^{26}$ A. Louant, La grande pitié des Archives de l'État à Mons, in: Miscellanea historica in honorem Alberti De Meyer. Universitatis Catholicae in oppido Lovaniensi iam annos XXV professoris, ed. Bibliothèque de l’Université, [Recueil de Travaux d'Histoire et de Philologie, 3], Louvain 1946, p. 1341.

${ }^{27}$ Unlike the main source of this study, the separate documents that are preserved in their original form, are still accessible in the State Archives in Mons.

${ }^{28}$ See for in institutional history of Hainaut: C. Piérard, Mons (moyen âge), in: Les institutions publiques régionales et locales en Hainaut et Tournai/Tournaisis sous l'Ancien Régime, ed. F. Mariage, [Miscellanea Archivistica Studia, 119], Brussels 2009, p. 247-257; J.-M. Cauchies, Le Hainaut et le Tournaisis au fil du temps (XIe-XVIIIe siècle). Histoire et pouvoirs, in: Créer, administrer, réformer. Regards croisés sur dix siècles d'histoire des institutions publiques en Hainaut et Tournaisis, ed. J.-M. Cauchies, L. Honnoré and F. Mariage, [Miscellanea 
of time was expanded from 1345 to 1467, from the beginning of the Bavaria-dynasty until the death of the first Burgundian duke in Hainaut. Taking these chronological definitions into consideration, the source corpus used in this study consists, next to the main source, of 255 deeds of which 183 (c. $72 \%)$ were issued by hommes de fief and 72 (c. 28\%) by notaries. Of all these documents, 146 have still been preserved as originals, whilst the remaining 109 are accessible through scholarly editions ${ }^{29}$. The sources are derived from the collection of contracts by hommes de fief ${ }^{30}$, the comital archives or Trésorerie des comtes de Hainaut ${ }^{31}$ as well as archives of religious institutions, such as the chapter of Saint Waltrude ${ }^{32}$.

What follows, is both a qualitative and in-depth content analysis of the fifteenth-century formulary from Hainaut accompanied with preliminary hypotheses concerning the three

Archivistica Studia, 182], Brussels 2009, p. 29-39; F. Mariage, Le territoire, in: Les institutions publiques régionales et locales en Hainaut et Tournai/Tournaisis sous l'Ancien Régime, ed. F. Mariage, [Miscellanea Archivistica Studia, 119], Brussels 2009, p. 27-38.

${ }^{29}$ Partially because of the unfavorable preservation conditions of the source material in the archives, some of the original pieces are hard to read and additional heuristic tools (e.g. repertories, inventories or critical editions) were necessary to gain more insights about the specific content of the documents.

${ }^{30}$ This collection of contracts, consisting of 4787 pieces or thirteen meters of archival documents, is partially preserved and divided into four different sections: Avis père et mère, Contrats de mariage, Partages and Testaments. In the late nineteenth century these sources were rudimentary disclosed and listed by means of data sheets by a certain A. Wéry, of whom nothing more is known: G. Broeckaert, Les hommes de fief de plume en Hainaut, Comptes-Rendus des Conférences du Cercle Archéologique et Historique de Valenciennes, 86 (2011), p. 1. Of this extensive collection 42 documents were used in this contribution. More specifically, they involve eight parental donations or avis de père et mère, nineteen marriage contracts or contrats de mariage, four divisions or partages and eleven testaments or testaments: State Archives in Mons (S.A.M.), Collection contrats des hommes de fief: avis de père et mère, 1, 3-4, 98-99, 383 and 406-407: S.A.M., Collection contrats des hommes de fief: contrats de mariage, 3-7, 699-700, 703-704, 706-707, 819, 1799-1802 and 1990-1992; S.A.M., Collection contrats des hommes de fief: partages, 573, 600-601 and 630; S.A.M., Collection contrats des hommes de fief: testaments, 1-2, 603-604, 697, 1343, 1464-1465 and 1529.

${ }^{31}$ In 1985, Gabriël Wymans published a detailed inventory of this archival fund: G. Wymans, Inventaire analytique de chartrier de la Trésorerie des comtes de Hainaut, Brussels 1985. From the comital archives 101 charters were consulted, among which some notarial instruments. Several documents are included in Devillers' Cartulaire des comtes de Hainaut, offering 36 additional sources: L. Devillers, Cartulaire des comtes de Hainaut, de l'avènement de Guillaume II à la mort de Jacqueline de Bavière, Brussels 1881-1896.

${ }^{32}$ Although this archival fund was equally burnt down in flames, the sources were edited by Devillers in his Chartes du chapitre de Sainte-Waudru de Mons, of which the second and third volume offered 76 additional sources: L. Devillers, Chartes du chapitre de Sainte-Waudru de Mons, Brussels 1899-1913. 
research questions. Next, these hypotheses will be assessed by means of the separate deeds of hommes de fief, that will be approached in a quantitative manner to unveil general tendencies. Lastly, these intermediate findings will be compared to contemporary notarial instruments that, because of their modest amount, will be analyzed in both a quantitative and qualitative way. The asset of such a threefold methodological framework is that it offers the opportunity to treat this research topic more nuanced and refined.

\section{The authors: institutionalization of customary law}

\subsection{A silent witness of change}

In the fifteenth century, constituents or 'appearers' had their private transactions validated by their preferred hommes de fief or by the ones that were immediately available ${ }^{33}$. This custom thus manifested in an ad hoc practice that was strongly determined by coincidence and personal favoring ${ }^{34}$. Comital vassals were not able to meet the increasing demand to have conventions recorded as written documents due to their modest numbers and because many of them were often illiterate. They were forced to rely on so-called clercs lettriants or clercs échoppiers for the actual redaction of the deed or charter ${ }^{35}$. To better anticipate on existing societal needs, these itinerant scribes received a symbolic annuity through which they were 'promoted' to comital vassals and were from then on, as hommes de fief sur plume, able to draft a charter and validate it with their proper seal ${ }^{36}$. Though this evolution points to a certain

\footnotetext{
${ }^{33}$ Devillers, Cartulaire des comtes (supra, n. 31), 3, p. 464-465; C. J. B. F. Faider, Coutumes du pays et comté de Hainaut, [Recueil des Anciennes Coutumes de la Belgique], 1, Brussels 1871, p. 100-101.

${ }^{34}$ Cacheux, Les notaires (supra, n. 11), p. 47; Louant, Les hommes (supra, n. 11), p. XIV.

35 These clercs lettriants or échoppiers were professional and public scribes who travelled to different cities and villages throughout the county and on the spot offered their services to whoever wished to appeal to them. In the early fifteenth century these scribes were mostly active in the city of Mons, since the count's sovereign court was located there: Louant, Les hommes (supra, n. 11), p. XVII-XVIII.

${ }^{36}$ Cacheux, Les notaires (supra, n. 11), p. 48; Louant, Les hommes (supra, n. 11), p. XXI-XXII. This yearly annuity initially consisted of an emasculated rooster or capon, that lived on a domain administered by the count's sovereign court. Due to inflation this annuity dropped in value until it consisted of the feather (plume) of a capon. Hence the denomination that was later used for designating these new officials.
} 
level of institutionalization of the customary law and a more rational, routinized organization of voluntary jurisdiction, it is not clear when this transition precisely occurred ${ }^{37}$. Nonetheless, the formulary offers several indications. As mentioned above, the manuscript contains extracts of transactions that, though they sometimes lack a datatio, have been recorded between 1406 and $1446^{38}$. Strikingly, most of the dated templates were originally drafted during the first quarter of the fifteenth century ${ }^{39}$. This probably coincided with an increasing demand to record private transactions. In line with this, it is plausible to assume that the formulary, that as such is an indication for the assumed institutionalization process, was composed in that same period, and that the transition from illiterate hommes de fief over clercs lettriants towards hommes de fief sur plume began around that moment ${ }^{40}$. After all, to redact their written documents and to better anticipate the increasing societal needs, the latter two groups most likely used 'formularies' that, for instance, contained practical guidelines ${ }^{41}$. That this new office of homme de fief sur plume was already known when the manuscript was redacted, is reflected in multiple templates that mention a certain Jean de Saint-Ghislain as both clerk and comital vassal. This might indicate that he was one of those new 'officials' ${ }^{42}$. The manuscript even mentions the names of other vassals, though it is not clear whether they

\footnotetext{
${ }^{37}$ Louant already implied that the transition towards hommes de fief sur plume must have been a long-term process that probably began from the fifteenth century onwards: Louant, Les hommes (supra, n. 11), p. XXI. ${ }^{38}$ The fifteenth-century formulary contains two charters from 1406 (G.U.L., ms. 2304: f. 7v.-8r.) and as many from 1446 (G.U.L., ms. 2304: f. 7r.-7v.).

${ }^{39}$ Out of these dated documents, sixteen were drafted between 1422 and 1435: respectively one in 1422 (G.U.L., ms. 2304: f. 3r.-3v.), two in 1426 (G.U.L., ms. 2304: f. 10v.-11v.), four in 1427 (G.U.L., ms. 2304: f. 9r.-10v. and 11v.-12r.), two in 1429 (G.U.L., ms. 2304: f. 6r. and 12r.-12v.), four in 1434 (G.U.L., ms. 2304: f. 13r.-13v. and 14v.-15r.) and three in 1435 (G.U.L., ms. 2304: f. 2r.-3r., 6r. and 14r.-14v.).

${ }^{40}$ Peter-Johannes Schuler equally related the circulation of such formularies to the institutionalization of voluntary jurisdiction and the rationalization of recording activities in notarial environments in Italy, France and Germany: P.-J. Schuler, Formelbuch und Notariat, in: Forma servata. Vijf opstellen over formulieren en formulierboeken in het notariaat van de middeleeuwen tot vandaag, ed. P. L. Nève and J. J. Verbeek, [Ars Notariatus, 85], Deventer 1998, p. 1-50.

${ }^{41}$ Louant, Les hommes (supra, n. 11), p. XLI.

${ }^{42}$ G.U.L., ms. 2304: f. 1r. and 7r. Jean de Saint-Ghislain appears in Wymans' repertory of vassals from Hainaut as well: G. Wymans, Répertoire d'armoiries sur sceaux des hommes de fief du comté de Hainaut, XIIIe-XVIIIe siècles, Brussels 1980, p. 129.
} 
were literate ones ${ }^{43}$. Interesting, however, is that their names show up in four different templates that were drafted in a short span of time, which raises the presumption that the number of vassals then began to increase. As such, one cannot help but wonder if, during their career, these hommes de fief recorded transactions on a regular basis or if their recording activities were rather infrequent in nature.

\subsection{Complex documentary realities}

Besides the indications the formulary offers, the selected source corpus allows to reconstruct the presumed institutionalization process in a more nuanced and detailed manner. When all the 255 consulted charters that have been recorded or validated between 1345 and 1467 in and around Hainaut, either by comital vassals or public notaries, are charted in a three-year time sequence, a peak in the overall recording practices for voluntary jurisdiction is noticeable from 1425 to 1440 , which confirms the earlier findings based on the formulary. Graph 1 shows that the societal need to have transactions recorded did indeed increase before the midfifteenth century, and as such, it confirms the hypothesis that the formulary was a tool to meet growing demands. Comparing this to the number of deeds recorded by hommes de fief, this peak was primarily caused by the performances of comital vassals who, as it seems, were quite able to respond to the assumed increasing needs.

\footnotetext{
${ }^{43}$ It involves Jehans Pickoix dis Machons or Jean Machon, Jacquemars de Tret, Jehans li Hiraux or Jean le Hiraut, Jehans de Presiel, Jehans de Morchipont, Prierars Candillons or Piérard Candillon, Jehans Cares, Simomies Cares and Henris de Haing. G.U.L., ms. 2304: f. 9r., 11v., 13r. and 14r. Of them, only Jean Machon, Jean le Hiraut and Piérard Candillon are recorded in Wymans' repertory: Wymans, Répertoire d'armoiries (supra, n. 42), p. 88, 106 and 112.
} 


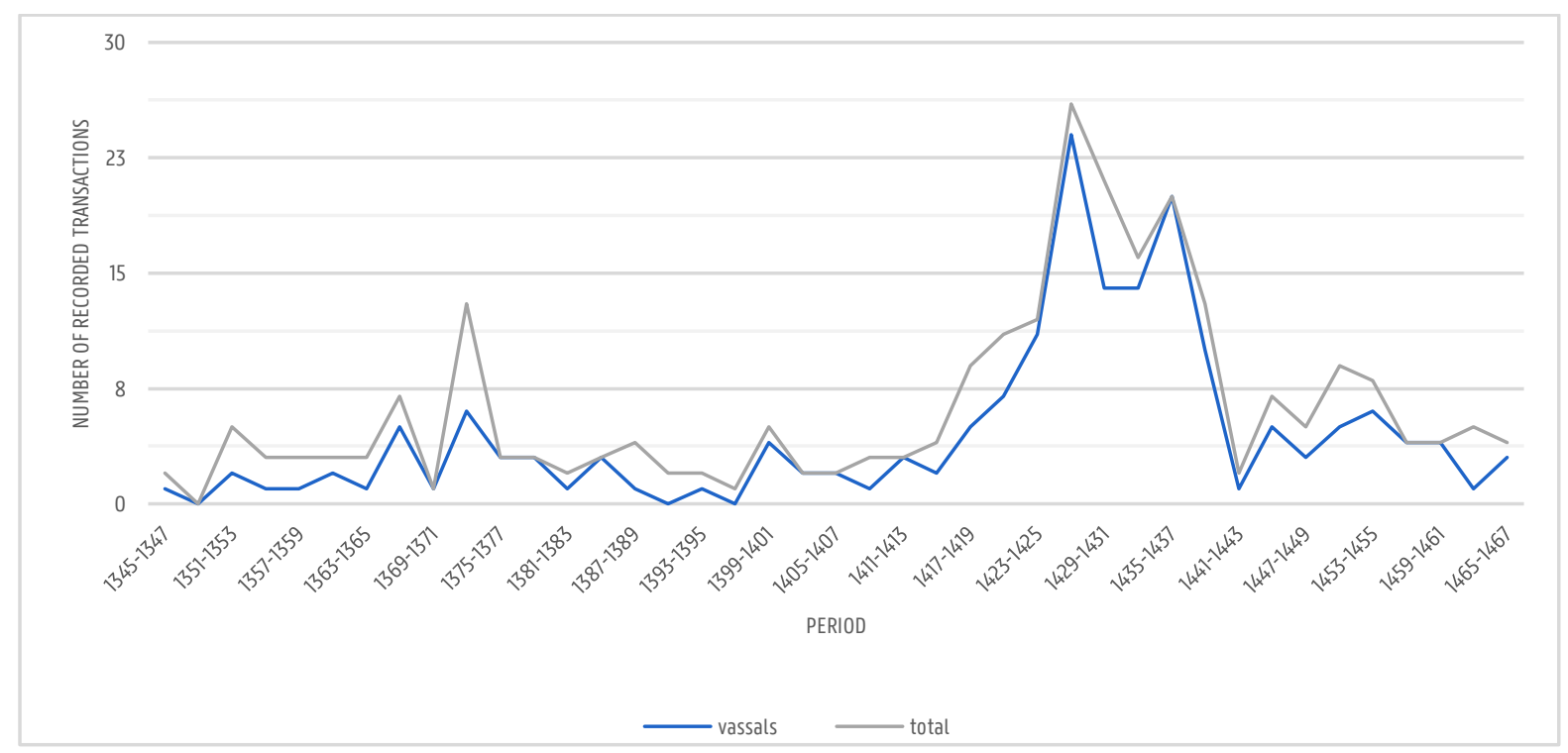

Graph 1: Recording activities of comital vassals in Hainaut, three-yearly, 1345-1467.

However, this assumption can only be confirmed through examining how the number of hommes de fief fluctuated during the time frame under consideration. In the 183 documents they have produced, no less than 355 different vassals are mentioned. Determining how many deeds each of them has recorded and when they did so, allows to estimate the period during which the individual vassals were active. Once again, a peak is noticeable in the graphic representation below (Graph 2) between 1423 and 1449, which implies that the number of comital vassals did indeed increase when the demand for written records of private transactions rose.

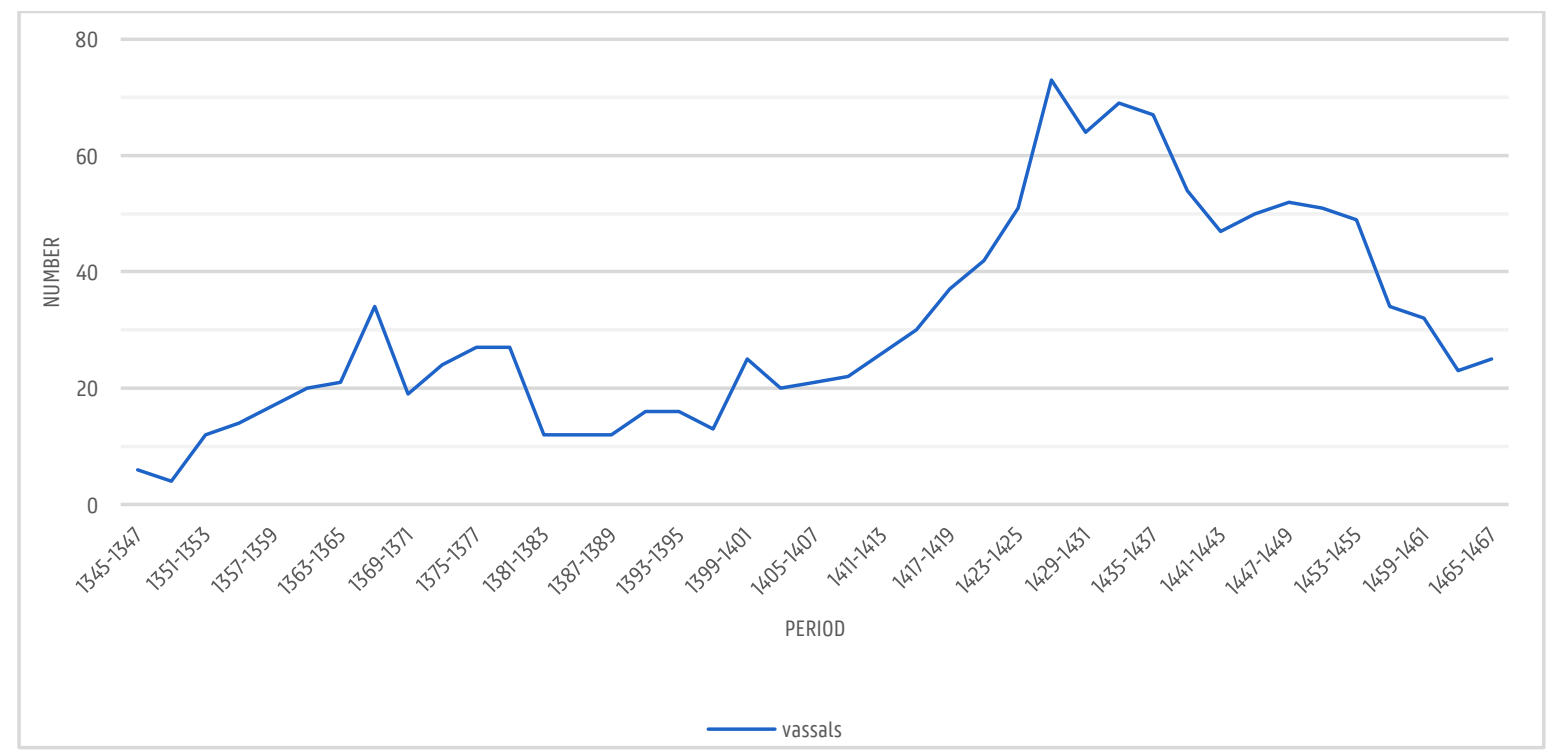

Graph 2: Periodic number of comital vassals in Hainaut, three-yearly, 1345-1467. 
This leaves the question to what extent there already was a routinely practice. To verify this, for every three years it will be determined how many vassals performed occasionally (recorded but one deed), regularly (validated two to six documents) and frequently (produced more than seven charters). The data in Graph 3 indicate that the former two groups appeared during the entire time frame at stake. From the 1420's onwards, vassals who knew a regular recording activity exceeded their counterparts who performed on an occasional basis. The third category of vassals who recorded frequently, was outnumbered and its activities were limited to a shorter span of time. Generally, it can be noticed that hommes de fief progressively became more active and recorded in a more systematic way, though this tendency was not pronounced in such a way that routine and rationalization could be assumed.

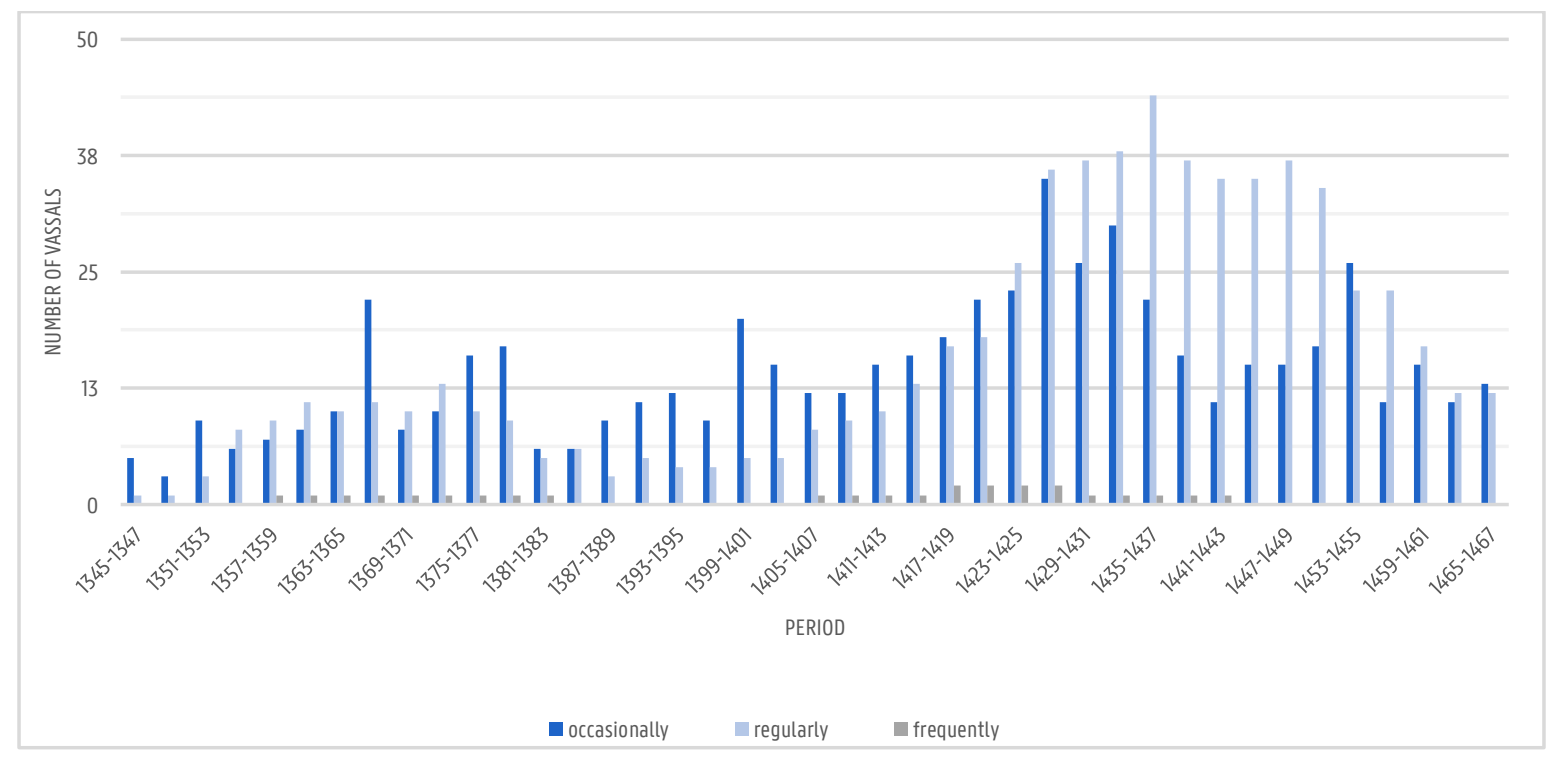

Graph 3: Recording intensity of comital vassals in Hainaut, three-yearly, 1345-1467.

One can thus conclude, albeit with some caution, that in the period 1345-1467 the first signs of institutionalization, through which customary practices to have personal transactions recorded gained a more routinely character, appeared. Revealing the exact moment of transition towards hommes de fief sur plume based on the available source material, however, is challenging. Since none of the documents name a vassal explicitly as such, one should look 
for indirect clues ${ }^{44}$. In 1980 Gabriël Wymans gathered the names of about 1.500 comital vassals from Hainaut between the thirteenth and eighteenth century ${ }^{45}$. Some of them he could identify as clerks, and of those in that capacity, nineteen occur in the charters consulted for this contribution ${ }^{46}$. Nonetheless, only seven out of those nineteen were explicitly mentioned as both homme de fief and clerc in the charters' intitulatio ${ }^{47}$. In hindsight, Wymans' repertory was not exhaustive: an additional analysis of the source material uncovered four more vassalclerks $^{48}$. That they were known as clerks, does not necessarily mean that these vassals redacted their own writings. However, when they signed the documents with their own signature or paraph, this most likely was the case. Ten hommes de fief single-handedly signed

\footnotetext{
${ }^{44}$ An additional challenge is that the hommes de fief sur plume were only registered from the sixteenth century onwards in the Registre des hommes de fief, of which the original was lost in the fire of 1940: Wymans,
} Répertoire d'armoiries (supra, n. 42), p. 27. However, prior to that, A. Wéry had rudimentary disclosed the register with data sheets: L. Honnoré, Guide des fonds et collections des Archives de l'État à Mons, Brussels 2006, p. 915. In 1959 copied the entire name list and accompanied it with an extensive introduction: Louant, Les hommes (supra, n. 11), p. 1-415. The register offers an overview of the names of more than 15.000 comital vassals from the ancien régime.

${ }^{45}$ Wyman did not list every vassal that was active in the county of Hainaut until the eighteenth century. He confined himself to the hommes de fief whose seals were still intact. As such, his contribution should rather be considered as a (heraldic) seal repository: Wymans, Répertoire d'armoiries (supra, n. 42), p. 77-138.

${ }^{46}$ Jean du Bos, Gérard Brongnart, Gilles Caudrelier, Simon Cazet, Jean Craspournient, Jean de Froimont, Colart de Gembloux, Jean Grenier, Jean l'Hoste, Gilles Hoston, Jean le Machon, Jean Masselot, Jean de Maurage, Simon Nockart, Lambert Paumet, Jean Pawillon, Henri Resteau, Jean le Roy and finally Jean de Saint-Ghislain: Wymans, Wymans, Répertoire d'armoiries (supra, n. 42), p. 83, 85, 89, 92, 100-101, 104, 107, 112, 116, 120 121 and 127-129.

${ }^{47}$ These were Jean du Bos, Gilles Caudrelier, Jean l'Hoste, Jean Masselot, Jean Pawillon, Jean le Roy and Jean de Saint-Ghislain: S.A.M., Avis père et mère, 407; S.A.M., Contrats de mariage, 707, 1800-1801 and 1991; S.A.M., Testaments, 1465; S.A.M., Trésorerie, 1412, 1482, 1486, 1489, 1518, 15751601 and 1718; L. Devillers, Cartulaire des comtes (supra, n. 31), 4, p. 243-244 and 650-651; L. Devillers, Cartulaire des comtes (supra, n. 31), 5, p. 382, 412-413, 427-428 and 468; L. Devillers, Cartulaire des comtes (supra, n. 31), 6, p. 113114, 214-215, 217-219 and 222; Devillers, Chartes du chapitre (supra, n. 32), 2, p. 339-341, 388-390, 402-404, 424-426, 476-477 and 492; Devillers, Chartes du chapitre (supra, n. 32), 3, p. 274-275. The latter was also mentioned in the Hainaut-formulary, in which he was identified as both vassal and clerk.

${ }^{48}$ In the original sources they are explicitly mentioned as both hommes de fief and clercs as well. Their names were Allart Nicaise, Jean le Fèbvre, Piérard Marchant and Gérard Seuwin: S.A.M., Contrats de mariage, 706; S.A.M., Partages, 573; S.A.M., Trésorerie, 1080, 1586 and 1587. 
their written documents ${ }^{49}$. Though each of these ten are referred to as homme de fief, only two of them are equally identified as $\operatorname{clerc}^{50}$. From this it can be assumed that vassals who drew their signature or paraph most likely were hommes de fief sur plume, especially when they acted as the clerk. By extension, it is fair to imply that vassals who were known to be clerks, but did not sign their documents, probably were hommes de fief sur plume as well - another indication that this type of profession was already known in the first half of the fifteenth century $^{51}$. A real breakthrough was not yet the case in this period, since in sum only about thirty hommes de fief, or roughly one-tenth of all the identified vassals between 1345 and 1467, were known as clerks ${ }^{52}$.

\subsection{No noble strangers}

Considering the main research question central to this contribution, it is interesting to unravel how 'ordinary' vassals and hommes de fief sur plume related to public notaries who were equally allowed to record private transactions within the county. There is no doubt that the notarial office was already known in Hainaut from the fourteenth century onwards. After all, pope Benedict XII (1285-1342), in a papal bull, granted the bishop of Tournai the privilege to appoint three episcopal notaries or apostolic tabelliones who would be operating in Hainaut ${ }^{53}$.

\footnotetext{
${ }^{49}$ It involves Jaquemart Corosty, Ansiau Dorennis, Baudouin Gessuin, Jean Grenier, Jean Masselot, Amand Mathieu, Hanin du Ponchiaul, Gérard Seuwin (supra, n. 48), Jean Testart and Nicaise Wiart: S.A.M., Contrats de mariage, 6-7, 703-704, 707, 1800 and 1991-1992; S.A.M., Partages, 600; S.A.M., Testaments, 2 and 1464.
} Wymans, however, did not include the names of Dorennis, du Ponchiaul, Seuwin and Testart in his seal repertory.

${ }^{50}$ Only Jean Masselot (supra, n. 49) en Gérard Seuwin (supra, n. 48) are identified as both comital vassals and clerks in the original charters.

${ }^{51}$ Probably, hommes de fief sur plume already existed in the county before the mid-fifteenth century. Gilles Caudrelier, among others, who was designated as vassal-clerk, was active between 1354 and 1362 in Mons and, partially, Frameries: Devillers, Chartes du chapitre (supra, n. 32), 2, p. 339-341, 388-390, 402-404 and 424-426. ${ }^{52}$ These 30 presumed hommes de fief sur plume could be identified due to the fact that they (1) were mentioned as clerks in Wymans' seal repertory; (2) were designated as clercs in the documents; (3) signed their writings with a paraph next to their proper seal.

${ }^{53}$ Cacheux, Les notaires (supra, n. 11), p. 46-47; Louant, Les hommes (supra, n. 11), p. XXX-XXXI; Wymans, Inventaire analytique (supra, n. 31), p. 156. See for an edition of the mentioned papal bull: E. Prud'homme, Les échevins et leurs actes dans la province de Hainaut, Mons 1891, p. 12-13. 
In that same period, at least two public notaries were active in the county ${ }^{54}$. This should not be surprising, because elsewhere in the Southern Low Countries, in the bishoprics of Liège and Tournai for example, episcopal notaries equally co-existed with their public counterparts $^{55}$. Analyses of the separate instruments reveal that this co-existence continued in the fifteenth century: between 1345 and 1467, besides three episcopal notaries, there were equally 41 public notaries active, of whom five explicitly indicated in their subscriptio to have been residing in the county ${ }^{56}$. Even though notaries were indeed instrumenting in Hainaut, opposed to what has long been assumed in historiography, their impact on the contemporary society should not be overestimated. Comparing the notarial and overall recording activities concerning voluntary jurisdiction shows that public notaries were still not quite able to meet the increasing demand for recording private transactions by the midfifteenth century. However, the importance of a notary public in Hainaut cannot be minimalized: Graph 4 below reveals a peak in the notarial activities between 1369 and 1377 , which suggests that during this period notaries responded to a brief and a slightly modest increased demand to record deeds of voluntary jurisdiction.

\footnotetext{
54 These were Arnould de Saint-Ghislain and Jacques du Moulin. Several years earlier, Jacques 'dit Roussiaus' and Olivier Vigerii de Landerneau were equally active as notaries in Hainaut. See: V. Van Camp, De oorkonden en de kanselarij van de graven van Henegouwen, Holland en Zeeland. Schriftelijke communicatie tijdens een personele unie. Henegouwen, 1280-1345, [Schrift en schriftdragers in de Nederlanden in de middeleeuwen, 5], Hilversum 2011, p. 50-53, 67-68, 78-80 and 92-94.

${ }^{55}$ Pieyns-Rigo, Notaires d'officialité (supra, n. 9), p. 311-314; Vleeschouwers-Van Melkebeek, Notaires d'officialité (supra, n. 9), p. 87-88.

56 The subscriptions (and notarial marks) of both Philippe Amiran and Hugues de Braine, who originated from Maubeuge and Mons, are still preserved in their original form: S.A.M., Trésorerie, 1065, 1391-1392 and 1405 ; Devillers, Cartulaire des comtes (supra, n. 31), 3, p. 282-283 and 497-98; Devillers, Cartulaire des comtes (supra, n. 31), 4, p. 214-215. The subscriptiones of Guillaume d'Ausnoit and Robert de Brabant, as well as those of Pierre de Brabant, respectively residing in Mons and Soignies, are only preserved through copies: Devillers, Chartes du chapitre (supra, n. 32), 2, p. 258-260, 450-452, 531-535, 627-631 and 702-705; Devillers, Chartes du chapitre (supra, n. 32), 3, p. 42.
} 


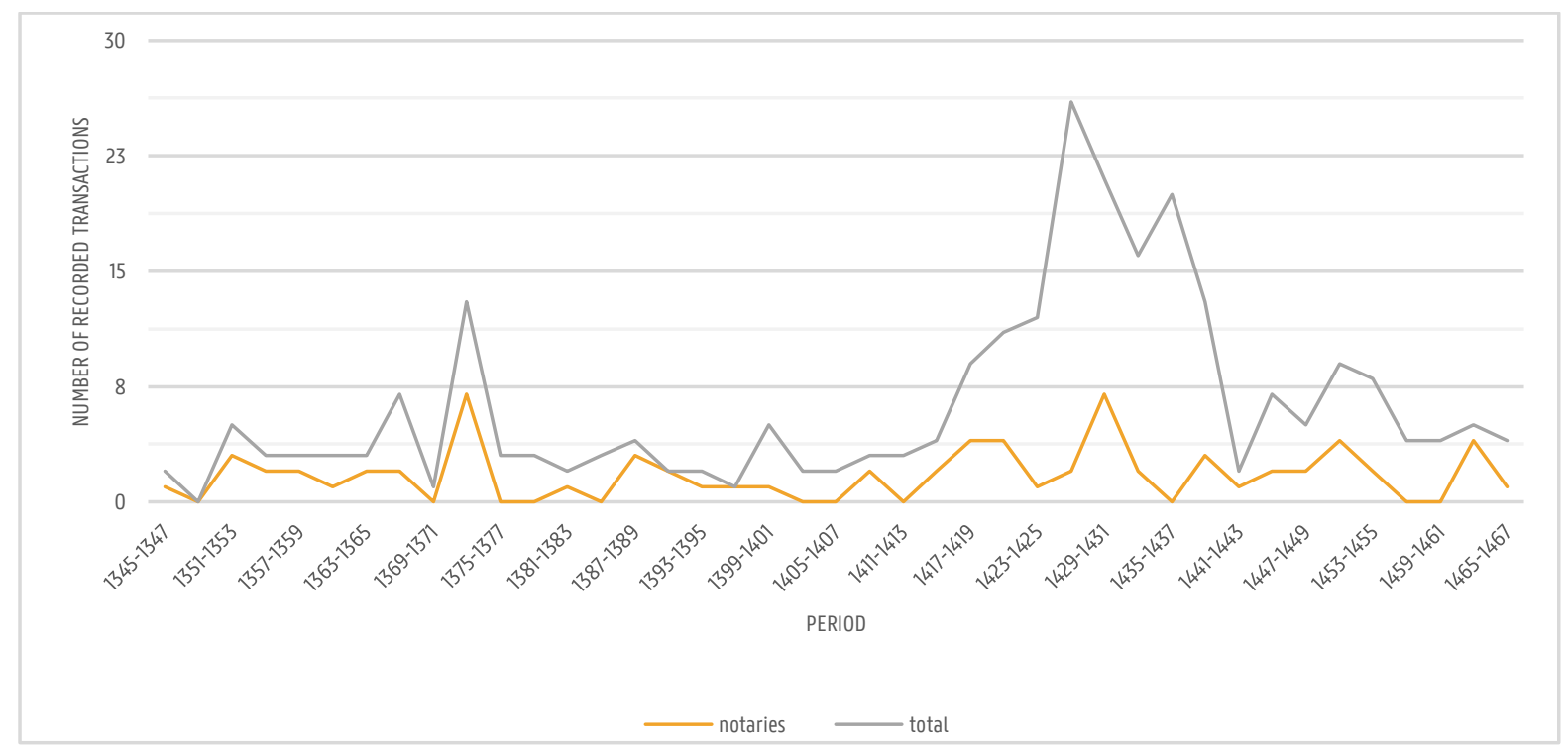

Graph 4: Recording activities of notaries in Hainaut, three-yearly, 1345-1467.

At the same time, the above graph shows that, although their recording activities were modest, especially compared to those of hommes de fief, their presence remained somewhat stable and did not suffer from the dominating vassals between 1423 and 1449. Moreover, the number of notaries did not fluctuate considerably (Graph 5), which suggests that the notary public was not some trivial phenomenon, but rather a steady one that, nevertheless, was not able to penetrate the county of Hainaut, due to the firm presence of other 'competing' groups such as 'ordinary' vassals and hommes de fief sur plume.

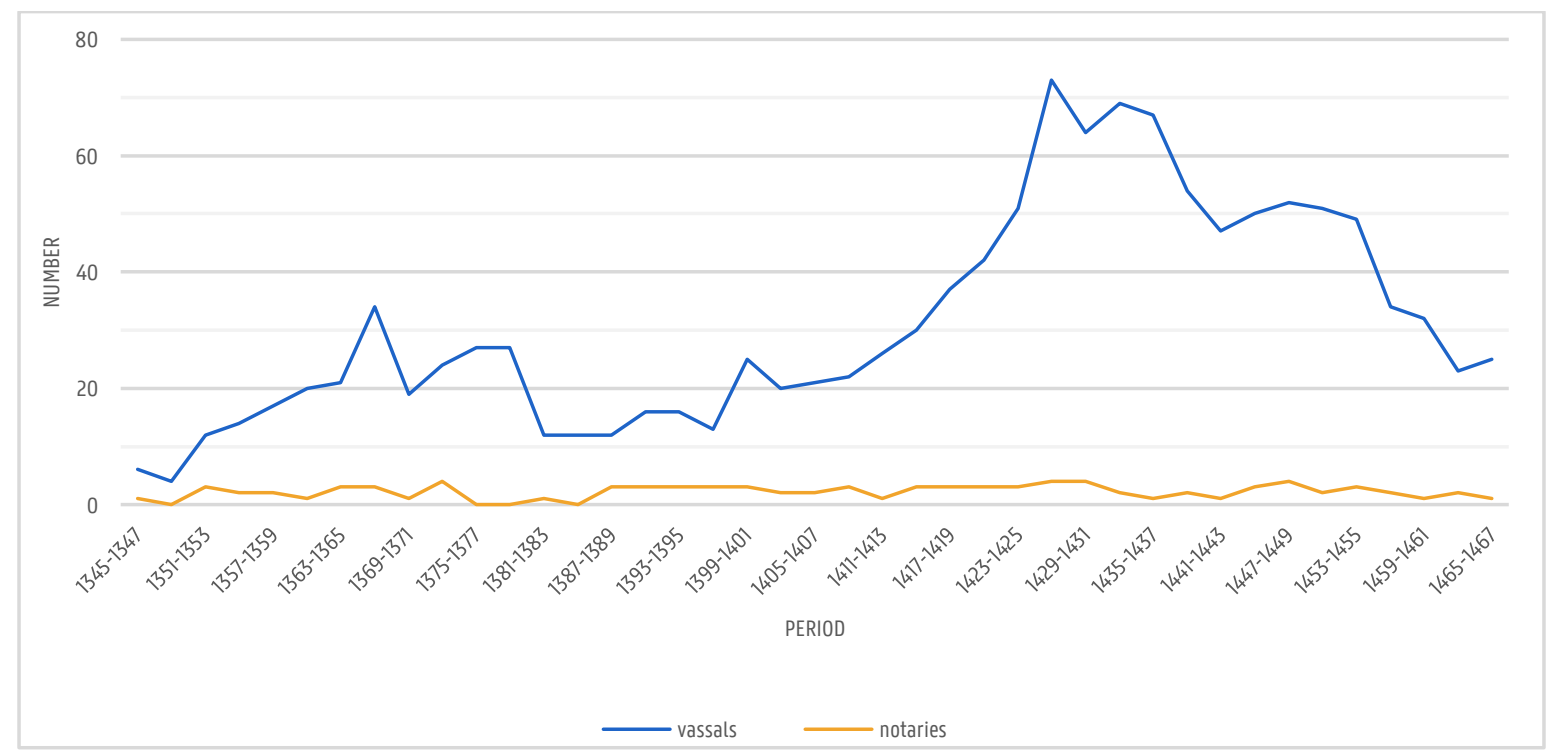

Graph 5: Number of active notaries and comital vassals in Hainaut, three-yearly, 1345-1467. 


\section{The documents: public trust at stake}

\subsection{From bonds to testaments}

Despite the tendency towards institutionalization, through which the office of hommes de fief sur plume became more adequate to meet the existing societal needs, it seemed that 'ordinary' vassals still had the biggest share in recording private transactions. Since many of them were illiterate, they had to rely on clercs lettriants who redacted the documents, but these scribes could not authenticate them. When a charter was redacted by such a scribe, it had to be validated by at least two comital vassals ${ }^{57}$. But in what kinds of legal transactions could these vassals intervene and how did they claim fides publica? Once again, the formulary is the theoretical point of departure. As described above, the compilers of this manuscript divided the different templates into multiple categories which they provided of a title. This categorization offers some indications about the competences of hommes de fief concerning voluntary jurisdiction ${ }^{58}$. A closer analysis shows that, to some extent, they were competent to record and authenticate bonds (obligation), leases (lieuwier), feu-duties (cense), receipts (quittance), purchases (accat), procurations (establissement) and testaments. The formulary equally contains templates of deeds that do not mention vassals, but instead the aldermen of Valenciennes among others, which indicates that the compilers themselves were no hommes

\footnotetext{
57 This was stipulated by law: Devillers, Cartulaire des comtes (supra, n. 31), 3, p. 465; Faider, Coutume du pays (supra, n. 33), 1, p. 101. According to Cacheux this a consequence of the fact that hommes de fief, in whichever capacity, were not competent to act by themselves. As such, they intervened with two or three, though there are cases known in which multiple vassals recorded or validated a private transaction: Cacheux, Les notaires (supra, n. 11), p. 50.

${ }^{58}$ Although Louant had previously attempted to reconstruct the competences of hommes de fief, it was appropriate to nuance his former insights based on the formulary. After all, Louant himself recognized the limitations of his methodological approach: Louant, Les hommes (supra, n. 11), p. XLII.
} 
de fief, but probably clercs lettriants ${ }^{59}$. After all, these public scribes were not only in service of comital vassals but offered their services to instances and people as well ${ }^{60}$.

\subsection{Vassals as key figures}

To determine what types of deeds vassals recorded, for each of their 183 documents it was examined what kind of legal transactions they included. These transactions can be divided into ten different categories ${ }^{61}$. Based on Graph 6 below, even though the available source material possibly causes a distortion, hommes de fief mostly produced authentic copies (vidimus) during the time frame under consideration. Besides that, comital vassals were likewise competent to record and validate testimonies, marriage contracts, purchases and settlements. To a somewhat lesser extent, they could equally be consulted for partitions (partages), testaments and wills, annuities, procurations and leases.

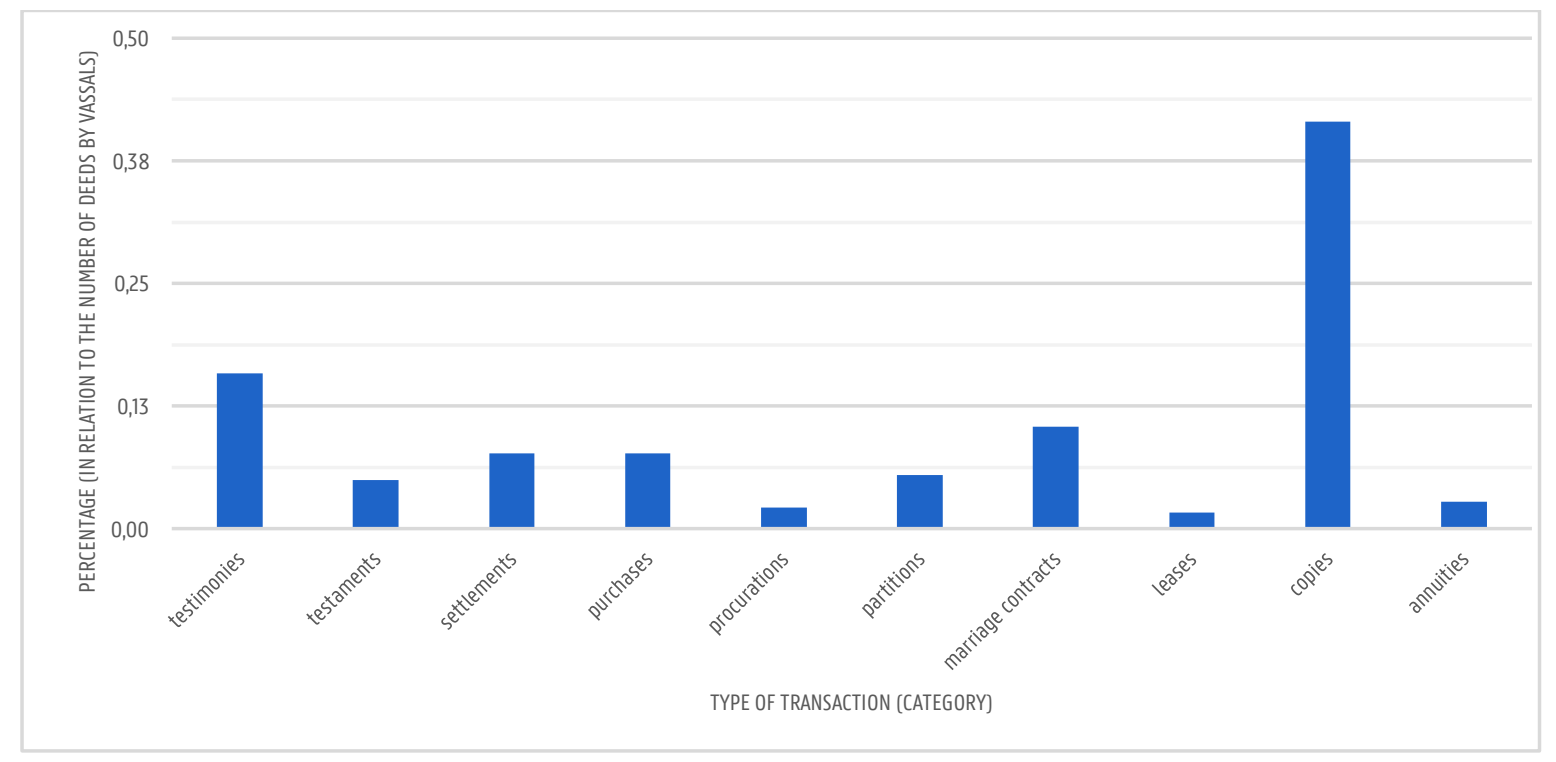

\footnotetext{
${ }^{59}$ Earlier, van Dievoet pointed this out as well: van Dievoet, Notarisboeken (supra, n. 25), p. 76. Should the compilers of the manuscript have been vassals themselves, they would probably have not inserted documents that do not mention any homme de fief.

${ }^{60}$ Louant, Les hommes (supra, n. 11), p. XLI.

${ }^{61}$ Inspiration for these different categories was found in the database of the Notarius-project that was initiated in 2017 by the State Archives in Courtrai and Louvain. The project's aim is to disclose notarial archives from the ancien régime with the help of volunteers: State Archives in Belgium, Notarius, URL: www.arch.be (consulted on November 22, 2018).
} 
Graph 6: Competences of comital vassals in Hainaut, 1345-1467.

To map the geographical scope of vassals, one must know where the documents were issued or drafted. Of 90 charters it is unknown where they were redacted. The other 93, except for one, appear to have been written down in Hainaut, in the city of Mons ${ }^{62}$. As such, it is quite fair to say that the competences of hommes de fief were limited to the county itself. A closer look into the exact regions where the comital vassals were active, offers some indications about their mobility. For 245 out of the 355 attested vassals, it was possible to determine their geographical scope: 222 were active in only one area, twenty-three in two. Only four of the latter group were equally active outside of Hainaut ${ }^{63}$. Every other vassal exclusively operated within the borders of the county, in most cases in or around the capital ${ }^{64}$. The data thus shows that hommes de fief were not very mobile - a possible indication that many of them were indeed not yet hommes de fief sur plume, for earlier research has shown that those officials were far more mobile and, as such, more often visited the constituents themselves ${ }^{65}$.

As for the clientele of comital vassals, lastly, they appear to have mainly consisted of lay people, rather than of clerics. After all, of the 183 consulted written documents of vassals from Hainaut, forty belong to four archival funds that together form the extensive contract collection of hommes de fief ${ }^{66}$. None of these mention clerics, as each time lay people are the requesting party. That most of their charters are preserved in the comital archives, the Trésorerie, is an additional justification to argue that vassals mainly intervened on behalf of a lay audience. A similar statement can be made for twenty-five of their documents that have been edited by Devillers in his Cartulaire des comtes de Hainaut. Only thirty-four of their writings belonged to the archives of the chapter of Saint Waltrude at the time and are thus included in Chartes du chapitre de Sainte-Waudru.

\footnotetext{
${ }^{62}$ This must have been the case until at least the fifteenth century, according to Louant. The comital court was situated in Mons: Louant, Les hommes (supra, n. 11), p. XVIII.

${ }^{63}$ Piérard Candillon and Jean Ghelet were, besides in Mons, equally active in Ghent, while Nicaise Brassauls and Philippe Wadrupont were attested in Cielle based on their writings: Wymans, Répertoire d'armoiries (supra, n. 42), p. 88 and 101; S.A.M., Testaments, 604.

${ }^{64}$ Cauchies, Le Hainaut (supra, n. 28), p. 29-39; Mariage, Le territoire (supra, n. 28), p. 27-38; Piérard, Mons (supra, n. 28), p. 247-257.

${ }^{65}$ Louant, Les hommes (supra, n. 11), p. LII-LIII. See also: Broeckaert, Les hommes (supra, n. 30), p. 1-3.

66 See supra, n. 30.
} 


\subsection{Shared interest or mutual competition?}

A similar approach of the 72 analyzed notarial instruments indicates that the nature of notarial competences did not differ substantially from that of comital vassals. Nonetheless, notaries did not record marriage contracts, nor any deeds concerning annuities. They did, however, produce considerable amounts of testaments, settlements, testimonies and leases, as well as, to a lesser extent, procurations, authenticated copies, purchases and partitions. Graph 7 below shows a comparison between the competences of notaries and those of hommes de fief and clarifies how the activities of both legal actors related to one another.

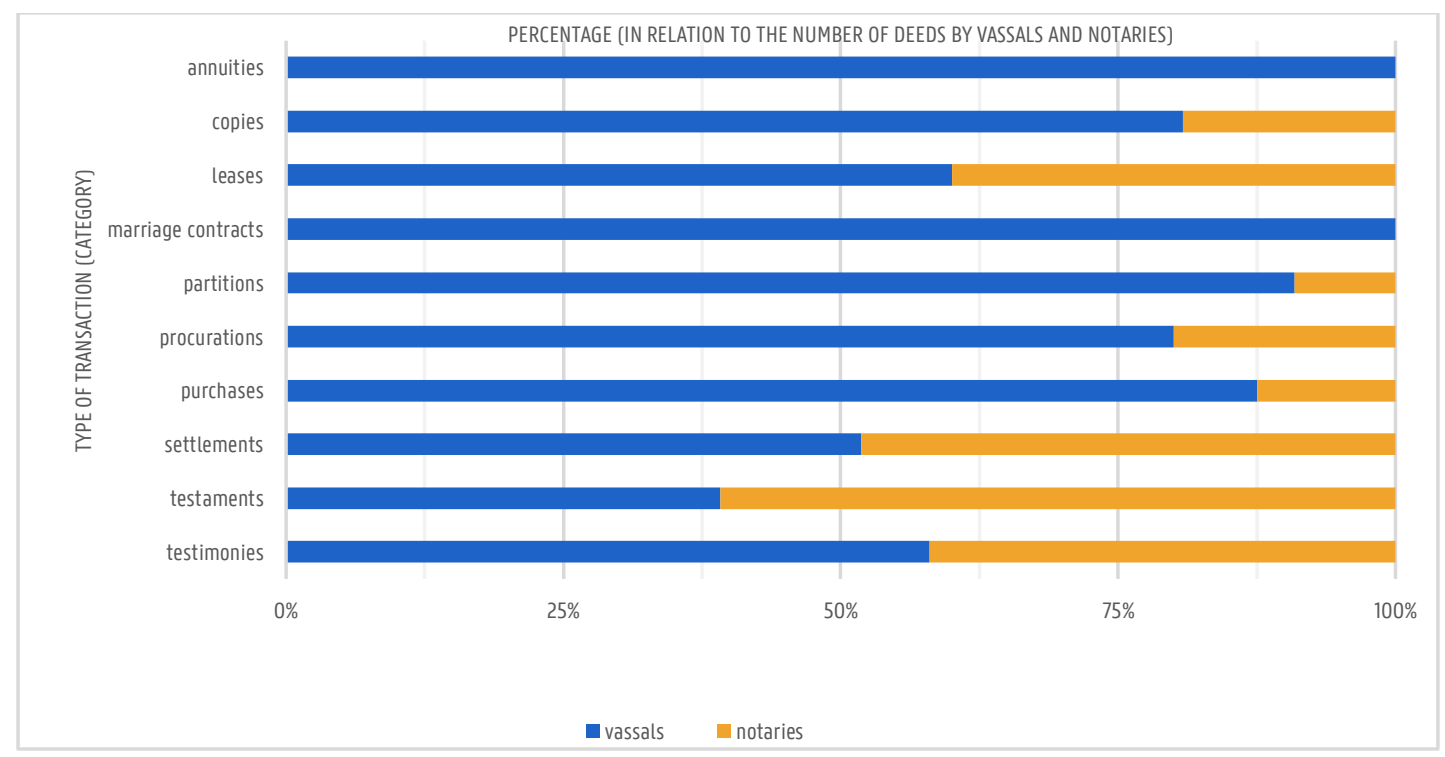

Graph 7: Competences of notaries and comital vassals in Hainaut, 1345-1467.

Other than the charters of hommes de fief, notarial instruments have an additional feature that allows to map the geographical area and mobility of notaries: often, their writings mention the place where the legal transaction was recorded, but at the same time, notaries single-handedly added their own subscription (subscriptio) through which it is able to determine where they came from ${ }^{67}$. Both the place indications and the notarial subscriptions in the documents are

\footnotetext{
${ }^{67}$ The notarial subscription is a discursive formula in which the notary identifies himself and by which he declares having redacted the instrument. By placing his mark, he takes full responsibility for the content of the document and provides it with an authentic character: Cárcel Ortí, Vocabulaire international (supra, n. 22), p. 67.
} 
important to reconstruct the work area of notaries who were active in and near Hainaut. Of the 72 consulted notarial acts, 53 explicitly mention where they were redacted. The majority, 48 documents, were issued within the borders of the county and mostly in the city of Mons. In turn, those 48 instruments were drafted by 23 different notaries. Although of five of them not much is known ${ }^{68}$, there are details about the eighteen others. Apart from Nicolas Tassardi, who was affiliated with the diocese of Tournai, they all came from the diocese of Cambrai, to which the county of Hainaut belonged at the time. Eleven of those notaries originating from Cambrai did not mention a specific residence in their subscription, while the other six did so. Étienne Wiard came from Tongeren and the other five from Hainaut: Guillaume d'Ausnoit, Hugues de Braine and Robert de Brabant resided in Mons, Pierre de Brabant in Soignies and Philippe Amiran in Maubeuge ${ }^{69}$. However, these notaries did not necessarily or exclusively instrument in their own city, which implies that they were more mobile than vassals ${ }^{70}$. This was the case with Robert de Brabant: he recorded at least one document in the city of Cambrai, far outside the borders of Hainaut ${ }^{71}$. The four remaining instruments that were issued outside the county, were drafted by Jakemes de Braine, Gilles Creton and Jean Flamingi. Of them is merely known that they originated from the diocese of Cambrai. Still, they might have instrumented in Hainaut as well: as was explained earlier, the county was part of that diocese and many notaries affiliated with Cambrai were active in Hainaut. Nineteen out of the 72 notarial deeds do not mention a specific place. Since these documents belong to the comital archives, the Trésorerie, or the chapter archives of Saint-Waltrude, there is a possibility that these instruments were equally recorded in the county. They were thus deliberately included in the source corpus of this contribution. As such, it is worth examining where the seventeen notaries who recorded them, exactly came from. For three of them that

\footnotetext{
${ }^{68}$ More specifically, the notaries Evrard de Vivariis, Henri de le Jauche, Jean Judiniel, Jean Polie and Nicolas le Viel. That very little is known about them, is a result of their subscriptions or subscriptiones being illegible or omitted from their respective scholarly editions.

${ }^{69}$ S.A.M., Trésorerie, 1065, 1391-1392 and 1405; Devillers, Cartulaire des comtes (supra, n. 31), 3, p. 282-283 and 497-498; Devillers, Cartulaire des comtes (supra, n. 31), 4, p. 214-215; Devillers, Chartes du chapitre (supra, n. 32), 2, p. 258-260, 450-452, 531-535, 627-631 and 702-705; Devillers, Chartes du chapitre (supra, n. 32), 3, p. 42.

${ }^{70}$ Hugues de Braine, for example, was equally active near Saint-Ghislain and Philippe Amiran in Le Quesnoy: S.A.M., Trésorerie, 1065 and 1405; Devillers, Cartulaire des comtes (supra, n. 31), 4, p. 214-215.

${ }^{71}$ Devillers, Chartes du chapitre (supra, n. 32), 2, p. 531-35.
} 
was not possible to determine ${ }^{72}$. Seven came from the diocese of Cambrai ${ }^{73}$, three from that of Tournai $^{74}$, two resided in Liège ${ }^{75}$ and the remaining two in Tongeren and Thérouanne ${ }^{76}$. It can therefore be assumed, albeit with some caution, that public notaries in and near Hainaut between 1345 and 1467 were more mobile than the comital vassals and that their geographical scope was wider. Notaries who resided in the county did not necessarily instrument in their own city, but equally in other parts of Hainaut and sometimes even further away from the borders of their usual district. Apart from these residing officials, the county knew 'foreign' notaries as well: they mostly originated from the diocese of Cambrai but could have equally been affiliated with those of Tournai or Liège.

As was already mentioned above, the notaries whose instruments were consulted for this study, did not record any deeds concerning annuities or marriage contracts. The latter indicates that notaries mostly intervened on behalf of clerics, since they could not marry. This assumption can partly be confirmed as more than half of the 72 analyzed notarial instruments were part of the chapter archives of Sainte-Waltrude. Nonetheless, that a minority of these documents, 28 to be precisely, belonged to the comital archives, suggests that notaries, just like hommes de fief, did not operate for an exclusive clientele, but instead presented themselves as a 'neutral' recording instance.

\section{The guarantees: authenticity and legal validity externalized}

\footnotetext{
${ }^{72}$ Further information about Jean Judiniel, Antoine de Beaulieu and Simon Pourette is missing.

${ }^{73}$ These were Gilles Vituli, Étienne Kokiau, Jacques Fielvés, Simon de Lobbes, Jean Gobiniel, Jean Nazardi and Jean de Chimay, whose name suspects that he was a residing notary of Hainaut: S.A.M., Testaments, 606; S.A.M., Trésorerie, 934, 975, 1054, 1106, 1153 and 1178; Devillers, Cartulaire des comtes (supra, n. 31), 1, p. 361-362, 435-438 and 502-503; Devillers, Cartulaire des comtes (supra, n. 31), 2, p. 86-87, 214 and 409-410.

${ }^{74}$ Jacques le Monnier, Jacques Meunier and Jean Escauvaut each indicated in their instruments that they were active as public notaries in the diocese of Tournai: Devillers, Cartulaire des comtes (supra, n. 31), 1, p. 502-503; Devillers, Chartes du chapitre (supra, n. 32), 3, p. 305-306 and 336.

${ }^{75}$ Martin de Zoemeren and Ratgherus de Arbiel: S.A.M., Testaments, 692.

${ }^{76}$ Previously it was indicated that Étienne Wiard came from Tongeren: S.A.M., Trésorerie, 1286 and 1405 ;

Devillers, Cartulaire des comtes (supra, n. 31), 2, p. 509-511; Devillers, Cartulaire des comtes (supra, n. 31), 3, p. 317-320; Devillers, Cartulaire des comtes (supra, n. 31), 4, p. 214-215; Devillers, Chartes du chapitre (supra, n. 32), 3, p. 90-91. François du Kar came from Thérouanne: S.A.M., Trésorerie, 1106; Devillers, Cartulaire des comtes (supra, n. 31), 2, p. 214.
} 


\subsection{Experimenting with something different}

Though the customary practices concerning voluntary jurisdiction gradually institutionalized, 'common' vassals were still more dominant than the hommes de fief sur plume who had a rather modest impact on society. Nonetheless, both groups had the capacity to record and validate a wide range of various deeds. As the latter redacted their writings themselves, the former mostly remained illiterate, thus appealing to itinerant scribes ${ }^{77}$. As viri authentici habentes pondus testimonii they validated the charter by means of their own personal seal ${ }^{78}$. Because of this, it is interesting to determine whether sealing remained the primary method of validating at the time or if other means of authenticating, along with the rise of hommes de fief sur plume, became more common to guarantee the validity of written private legal transactions and mutual deeds ${ }^{79}$. Based on the formulary, it is often difficult to determine how the involved instances validated their records, since the compilers omitted stereotype formulas from their templates, such as the corroboratio ${ }^{80}$. The manuscript offers, nonetheless, some indications concerning the accepted methods of authenticating. Although only nine templates specifically mention validation signs, in each case one or more seals are involved ${ }^{81}$. This suggests that in the fifteenth century seals were still the most important way to validate private deeds among other things. Strikingly, the same manuscript shows that people began to experiment with different graphic signs in which, often, a person's name was integrated ${ }^{82}$.

\footnotetext{
${ }^{77}$ Louant, Les hommes (supra, n. 11), p. XVI-XVIII.

${ }^{78}$ Devillers, Cartulaire des comtes (supra, n. 31), 3, 465; Faider, Coutume du pays (supra, n. 33), 1, 101; Louant, Les hommes (supra, n. 11), p. XVI. When vassals had their deeds redacted by clercs lettriants, the documents had to be authenticated by at least two seals to be legally valid.

79 Throughout the Low Countries and in many parts of continental Europe, sealing was the most common practice from the twelfth century onwards: T. de Hemptinne, Les symboles graphiques dans les chartes du comté de Flandre jusqu'au début du XIIIe siècle, in: Graphische Symbole in mittelalterlichen Urkunden. Beiträge zur diplomatischen Semiotik, ed. P. Rück, [Historische Hilfswissenschaften, 3], Sigmaringen 1996, p. 510.

${ }^{80}$ The corroboratio-formula of a charter contains the validation signs (e.g. signatures or seals): Cárcel Ortí, Vocabulaire international (supra, n. 22), p. 65.

${ }^{81}$ G.U.L., ms. 2304: f. 2r.-3r., 7r.-7v., 9r.9v., 11r-11v. and 13r.-15r.

${ }^{82}$ It is not possible to identify these persons: none of them is specifically mentioned, not in Louant's edition of the Registre des hommes de fief, nor in Wymans' repertory. It thus remains unclear what capacity the scribes of these signa had at the time.
} 
Considering the mutual differences and nuances in the designs, it is fair to assume that multiple scribe hands drew them ${ }^{83}$. Presumably, the formulary was used among various professional scribes as some sort of practice source ${ }^{84}$. Despite their differences, the signs show similarities: they begin with a given name and a simplified paraph that, through a loop, forms a horizontal line underneath the name to assimilate with its vertical shafts. These clearly are the main characteristics of late medieval and early modern signatures ${ }^{85}$.

\subsection{Signs of an emerging individuality}

Even though these graphic signs or signa were not yet considered to be full-fledged validation signs - given the majority of deeds that were still sealed - it is not surprising that signatures and paraphs, just as seals, were reserved a prominent spot in the formulary. In a society that for the bigger part was still an illiterate one, both material and graphic signs, the so-called external characteristics of a charter, were equally important as the internal aspects, such as the textual discourse and style ${ }^{86}$. Obviously, these signs merely had (legal) value when they were issued by someone with authority: they visualized the authority of the issuer ${ }^{87}$. At the same time, these signa imply an increased degree of individuality, in that the discursive ego of the text received a concrete interpretation because of them ${ }^{88}$. More often, seals and signatures are

\footnotetext{
${ }^{83}$ Such graphic signs can be found in the front and the back of the manuscript, on the inside of the parchment cover, as well as on folio $11 \mathrm{r} ., 17 \mathrm{v} .-18 \mathrm{v}$. and 20r.-20v.

${ }^{84}$ Further paleographic and codicological (archival) research could reveal more details about the reception and use of the fifteenth-century manuscript.

${ }^{85}$ C. Jeay, L'autographie comme épiphanie du pouvoir. Écrits et signatures autographes des rois de France dans la seconde moitié du XIVe siècle, in: Manu propria. Vom eigenhändigen Schreiben der Mächtigen (13.-15. Jahrhundert), eds. C. Feller and C. Lackner, [Veröffentlichungen des Instituts für österreichische Geschichtsforschung, 67], Vienna 2016, p. 197-201.

${ }^{86}$ B.-M. Tock, Introduction, in: Les actes comme expression du pouvoir au Haut Moyen Âge. Actes de la Table Ronde de Nancy, 26-27 novembre 1999, eds. M.-J. Gasse-Grandjean and B.-M. Tock, [Atelier de Recherches sur les Textes Médiévaux, 5], Turnhout 2003, p. 12-13; de Hemptinne, Les symboles (supra, n.79), p. 510-512 and 517-518; Clanchy, From memory (supra, n. 17), p. 253-293.

${ }^{87}$ Clanchy, From memory (supra, n. 17), p. 294-327; Tock, Introduction (supra, n. 86), p. 13.

${ }^{88}$ B. M. Bedos-Rezak, When ego was imago. Signs of identity in the Middle Ages, [Visualising the Middle Ages, 3], Leiden 2011, p. 131 and 152.
} 
thus considered as expressions of both individuality and identity ${ }^{89}$. Applied to the used source corpus for this contribution, this can help to explain why all the 183 charters in which hommes de fief are specifically mentioned, were sealed ${ }^{90}$. Additionally, every seal contained a coat of arms that reaffirmed the identity of the sealer or issuer ${ }^{91}$.

The way in which validation signs shaped the medieval 'self' has long been neglected in historiography ${ }^{92}$. Only recently, scholars such as Brigitte M. Bedos-Rezak have given more attention to the semiotic relation between the sigillum and the sealer, or the representation and the human presence. According to Bedos-Rezak, seals are the incarnation of diplomatic 'self', through which the charter gained, in a way, physicality. The latter granted authenticity and authority to the written document ${ }^{93}$. Béatrice Fraenkel and Claude Jeay unveiled similar findings for signatures. As validation signs that authenticated a deed, they simultaneously consolidated the issuer's authority. They were personal marks as well, shaping the identity of the carrier and gradually becoming an emanation of the individual ${ }^{94}$. Although vassals used

\footnotetext{
${ }^{89}$ B. M. Bedos-Rezak, Introduction. Les marqueurs de l'individuation, in: L'individu au Moyen Âge.
} Individuation et individualisation avant la modernité, eds. B. M. Bedos-Rezak and D. Iogna-Prat, Paris 2005, p. 35-39. Besides this contribution, Bedos-Rezak emphasized the use of seals, while Clause Jeay focused on signatures: B. M. Bedos-Rezak, Signes d'identité et principes d'altérité au XIIe siècle. L'individu, c'est l'autre, in: L'individu au Moyen Âge. Individuation et individualisation avant la modernité, eds. B. M. Bedos-Rezak and D. Iogna-Prat, Paris 2005, p. 43-57; C. Jeay, La signature comme marque d'individuation. La chancellerie royale française, in: L'individu au Moyen Âge. Individuation et individualisation avant la modernité, eds. B. M. Bedos-Rezak and D. Iogna-Prat, Paris 2005, p. 59-77.

${ }^{90}$ Many of the original charters still contain some seals. Likewise, the abstracts or summaries in Wymans' inventory of the comital archives (Trésorerie) mention sealed deeds that have been recorded by hommes de fief. For those documents that are no longer preserved as originals and that are thus merely accessible through scholarly editions, Devillers specifically mentioned that the respective acts were sealed.

${ }^{91}$ Louant, Les hommes (supra, n. 11), p. XXXIX; Wymans, Répertoire d'armoiries (supra, n. 42), p. 29.

${ }^{92}$ Ever since the publication of De re diplomatica the field of sigillography mainly focused on how a seal consolidated the authority of the sealer or issuer: J. Mabillon, De re diplomatica libri VI, Paris 1681. The fifth volume involves the medieval use of seals. See also: R. P. Tassin and C.-F. Toustain, Nouveau traité de diplomatique, Paris 1759, p. 422-443; N. de Wailly, Éléments de paléographie, Paris 1838, p. 44-421; G. Tessier, Diplomatique royale française, Paris 1962, p. 190; M. Pastoureau, Les sceaux, [Typologie des sources du Moyen Âge occidental, 36], Turnhout 1981.

${ }^{93}$ Bedos-Rezak, When ego (supra, n. 88), p. 131 and 152.

${ }^{94}$ B. Fraenkel, La signature. Genèse d'un signe, Paris 1992, p. 18-19; Jeay, La signature (supra, n. 89), p. 59-63, $72-73$ and 79 . 
signatures, between 1345 and 1467 they were a rather marginal phenomenon in Hainaut: of the 355 identified hommes de fief only ten used a signature ${ }^{95}$. As mentioned above, these vassals probably redacted their own documents and were presumably hommes de fief sur plume. Nevertheless, only three of them can be identified as clerk ${ }^{96}$. It is not that astonishing that signatures were not fully known at the time. Even though their main developments already took place during the Valois-dynasty in Burgundy, their numbers only increased with Philip the Good and the phenomenon 'trivialized' not earlier than in the late fifteenth century, under the rule of Charles the Bold. Despite this, it is telling that vassals in Hainaut used their proper signatures. After all, by means of their signatures, that reveal some clear influences from the late-Capetian chancelleries, the earliest members of the Valois-dynasty attempted to align themselves in a longer governmental tradition to legitimize their authority ${ }^{97}$. Taking this into consideration, one can assume that the hommes de fief (sur plume) in Hainaut imitated a similar ideology and thus sought to associate themselves with the existing chancelleries in the county to gain public trust as well as to consolidate their professional-institutional authority ${ }^{98}$.

\subsection{Valuable information in the notarial subscription}

Other than vassals, notaries took full responsibility for the credibility and validity of their instruments by placing their notarial mark, seing manuel or signum, and their subscription or subscriptio ${ }^{99}$. These two solemnitates guaranteed the legal validity of the documents and were central to the contemporary rules of evidence that required a written document to comply with all the formalities so that it could be considered as an authentic instrument. Afterwards, the

\footnotetext{
95 See supra, n. 49.

${ }^{96}$ See supra, n. 50.

${ }^{97}$ A. Marchandisse and B. Schnerb, L'usage de la signature par les premiers ducs de Bourgogne de la maison de Valois, in: Manu propria. Vom eigenhändigen Schreiben der Mächtigen (13.-15. Jahrhundert), eds. C. Feller and C. Lackner, [Veröffentlichungen des Instituts für österreichische Geschichtsforschung, 67], Vienna 2016, p. 278-279.

${ }^{98}$ At the time, the (comital) chancellery could not yet ascertain a long tradition, though Van Camp pointed out that the most important impulses and developments took place between 1280 and 1345, right before the time frame under consideration in this study: Van Camp, De oorkonden (supra, n. 54), p. 13-18.

${ }^{99}$ See supra, n. 67.
} 
notary could use it to claim fides publica ${ }^{100}$. The personal and immutable notarial mark was usually placed left from the subscriptio. Initially, it rather served as a recognition symbol that had no validating value. Along with the earliest spread of the notarial office in these regions, non-sealed notarial instruments did not occur and written documents that had no seal, were suspicious. Gradually, however, the notarial mark vouched for the legal authenticity of the instrument and as such, it consolidated the notary's authority ${ }^{101}$. But its performative function did not end there. Just like the signature, the notarial mark contained an aspect of identity that individualized the notary ${ }^{102}$.

The subscription was as valuable as the notarial mark. It always appeared together with the latter and contained important information about the notary through which he could be identified $^{103}$. Based on the 72 notarial instruments that were analyzed for this study, 44 public notaries active in and near Hainaut could be identified. The original documents of 21 of them were still accessible: they contain both the notarial marks and the subscriptions of the respective notaries. Of the 23 remaining notaries their subscriptiones could only be reconstructed through the scholarly editions of their writings. These notarial subscriptions were important to gather prosopographical information about the origins and social status of the assessed notaries. Concerning their social status, it should be noticed that most of the public notaries who instrumented in Hainaut, were clerics and that some of them even received priesthood ${ }^{104}$. Mostly, these clerici had an imperial appointment, be it together with

\footnotetext{
${ }^{100}$ Oosterbosch, Vleeschouwers-Van Melkebeek, Pieyns-Rigo and Godding, Het notariaat (supra, n. 6), p. 76; M. Oosterbosch, De fide instrumentorum. De notariële oorkonde en haar bewijskracht in de middeleeuwen, in:
} Instrumentum quantum pactum. Zes opstellen over de kracht van de notariële akte vanaf de tijd van keizer Justinianus tot aan het huidige recht, ed. P. L. Nève, [Ars Notariatus, 51], Deventer 1991, p. 15 and 29-30. ${ }^{101}$ Oosterbosch, Vleeschouwers-Van Melkebeek, Pieyns-Rigo and Godding, Het notariaat (supra, n. 6), p. 8287; Oosterbosch, De fide instrumentorum (supra, n. 100), p. 27.

102 B. Fraenkel, Rebus-signatures, in: Sign and design. Script as image in cross-cultural perspective (300-1600 CE), eds. B. M. Bedos-Rezak and J. F. Hamburger, [Dumberton Oaks Symposia and Colloquia], Washington 2016, p. 82 .

${ }^{103}$ Oosterbosch, Vleeschouwers-Van Melkebeek, Pieyns-Rigo and Godding, Het notariaat (supra, n. 6), p. 49 and 82; Fraenkel, Rebus-signatures (supra, n. 102), p. 76.

${ }^{104}$ Nine notaries were known to be clerics at the time: Pierre de Brabant, Ratgherus de Arbiel, Jean de Chimay, Jean Escauvaut, Simon de Lobbes, Jean Meure, Jacques le Monnier, Jean Nazardi and Martin de Zoemeren. See: S.A.M., Testaments, 692. S.A.M., Trésorerie, 934, 975 and 1054; Devillers, Cartulaire des comtes (supra, n. 31), 1, p. 361-362, 435-438, 502-503 and 670-673; Devillers, Chartes du chapitre (supra, n. 32), 2, p. 258-60, 
an apostolic one, while only a minority was appointed by a papal delegate ${ }^{105}$. These findings correspond with those for public notaries in Flanders and Brabant ${ }^{106}$. At this stage, a prosopographical study into public notaries from Hainaut during the late Middle Ages is lacking, which makes it hard to determine to what extent their social and cultural background differed from their counterparts in the other regions of the contemporary Southern Low Countries.

\section{Conclusion}

In line with the main observation that the organization of voluntary jurisdiction in late medieval Hainaut differed from other parts of the Southern Low Countries, this contribution

331-334; Devillers, Chartes du chapitre (supra, n. 32), 3, p. 336. Ten even were priests: Rasse Andrelut, Hugues de Braine, Jacques Chevalier, Jean Gobiniel, Étienne Kokiau, Jacques Meunier, Jean Ponte, Michel Robaille, Jean de Saint-Vaast and Jean Tierasse. See: S.A.M., Contrats de mariage, 699; S.A.M., Partages, 600; S.A.M., Testaments, 606; S.A.M., Trésorerie, 934, 1286, 1391-1392, 1405 and 1583; Devillers, Cartulaire des comtes (supra, n. 31), 1, p. 361-362; Devillers, Cartulaire des comtes (supra, n. 31), 3, p. 282-283, 317-320 and 497498; Devillers, Cartulaire des comtes (supra, n. 31), 4, p. 214-215; Devillers, Cartulaire des comtes (supra, n. 31), 5, p. 469-470; Devillers, Chartes du chapitre (supra, n. 32), 3, p. 229, 233, 236-241, 251-253, 305-306 and 310. Of the remaining 25 notaries, further information about their social status is missing.

${ }^{105}$ Thirteen out of the 44 public notaries in Hainaut only had an imperial appointment. For Rasse Andrelut, Pierre de Brabant, Ratgherus de Arbiel, Jean de Chimay, Jean Meure, Jean de Saint-Vaast and Martin de Zoemeren: see supra, n. 104. For Robert de Brabant, Jacques Fielvés, Vincent de Haussi, François du Kar, Nicolas Tassardi and Jean de le Vigne: S.A.M., Trésorerie, 1106; Devillers, Cartulaire des comtes (supra, n. 31), 2, p. 214; Devillers, Chartes du chapitre (supra, n. 32), 2, p. 450-452, 483-489, 531-535, 598-600, 668-672, 702-705 and 725-727. Twelve had both an imperial and a papal appointment. For Hugues de Braine, Jacques Chevalier, Jean Escauvaut, Jean Gobiniel, Jean Nazardi, Jean Ponte and Michel Robaille: see supra, n. 104. For Guillaume d'Ausnoit, Gilles Creton, Nicaise Jonniau, Gilles Vituli and Étienne Wiard: S.A.M., Trésorerie, 1110-1112, 1153, 1158, 1178, 1286 and 1406; Devillers, Cartulaire des comtes (supra, n. 31), 2, p. 86-87, 409410, 435-37 and 509-511; Devillers, Cartulaire des comtes (supra, n. 31), 3, p. 317-320 and 621-622; Devillers, Cartulaire des comtes (supra, n. 31), 4, p. 214-15; Devillers, Chartes du chapitre (supra, n. 32), 2, p. 627-631 and 702-705; Devillers, Chartes du chapitre (supra, n. 32), 3, p. 42 and 90-91. Four only had a papal or apostolic appointment. For Étienne Kokiau and Simon de Lobbes: see supra, n. 104. For Philippe Amiran and Jakemes de Braine: S.A.M., Trésorerie, 1065; Devillers, Cartulaire des comtes (supra, n. 31), 1, p. 590-592. Of fourteen notaries it is not known what appointment they had.

${ }^{106}$ For references on this topic see supra, n. 10. 
aimed to further examine this case study that somewhat has been neglected so far. In doing so, it pointed out that it is crucial to consider the interactions between various intermediaries and existing, if not indigenous, alternatives to form a nuanced and fine-grained understanding of the specific interpretation of voluntary jurisdiction that, mainly in these former regions of customary law, were determined by local and regional developments. Equally, it revealed that the unilateral top-down view, that has been applied up till now to grasp the institutional characteristics of the most dominant agents for voluntary jurisdiction, is no longer appropriate and that an alternative approach is necessary. That is why central to this study was a novel bottom-up perspective that considered contemporary legal practices and that associated the broader theme with concepts such as 'pragmatic literacy', 'authority', and 'public trust' (fides publica). This theoretical framework offered the opportunity to better contextualize the seemingly untypical situation in the county of Hainaut and to gain more insight in the share of comital vassals, hommes de fief sur plume and public notaries in the organization of voluntary jurisdiction, as well as in the way they all employed pragmatic literacy to gain more status and to consolidate their authority as private legal recording instances. The main research question was approached from three more concrete sub-questions at the level of the authors, the documents and the guarantees, that were related to institutionalization, rationalization and professionalization on the one hand, and that evolved around the theoretical notions of 'public trust' and written 'authenticity' on the other. Applied to both a uniquely preserved formulary from Hainaut and a source corpus existing of 255 contemporary charters, this contribution showed that the professional activities of hommes de fief (sur plume) and notaries gradually institutionalized, though between 1345 and 1467 these tendencies were noticeable to a lesser extent. With the comital vassals this institutionalization manifested itself in intensification of their activities, a rise in their numbers and a systematic performance. At the same time, the progressive transition from illiterate vassals who appealed to itinerant scribes to compose their writings, towards hommes de fief sur plume who were competent, as both clerk and vassal, to redact and issue their own deeds, suggests a first step towards the institutionalization of the existing customary law. This new 'profession', however, had not yet fully penetrated society, and its impact was rather limited at the time. The same was true for public notaries in Hainaut whose recording practices and activities were quite modest compared to those of comital vassals. They nonetheless had a certain 'market share': during the fourteenth and fifteenth century, the activities of notaries in and near Hainaut were relatively stable and their numbers were less subjected to fluctuations, despite the proactive performances of comital vassals. Both agents equally succeeded to ascertain their authority 
within different legal aspects of society and were thus able to gain public trust. It should be mentioned that although both notaries and comital vassals had most of their competences in common, they did not share the same clientele nor geographical scope. As such, they cannot be considered as harsh rivals. This might explain why notaries have known a 'constant' recording activity during the fourteenth and fifteenth century, as well as why their numbers had not reduced, despite the growing importance of hommes de fief for voluntary jurisdiction. Each using specific validation marks that guaranteed the authenticity of their proper instruments, they were able to consolidate their institutional and professional authority as well as to express their social identity. In other words: both 'agents' within the legal field of voluntary jurisdiction could ascertain authority as private legal recording instances, which nuances former insights that clearly overestimated the importance of hommes de fief and misjudged the notary public in the county of Hainaut. 